\title{
Comparing Official and Public Attitudes towards Solar Energy in Botswana: The Case of Domestic Solar Water Heaters in Gaborone
}

\author{
Magdeline Cleopatra Nondo \\ Department of Environmental Sciences, University Of South Africa
}

\begin{abstract}
This study set out to compare household attitudes towards the use of domestic solar energy with those of government officials, with specific reference to Solar Water Heaters (SWHs) in the City of Gaborone in Botswana. The specific objectives were; i) To establish household perceptions and attitudes towards SWHs ii) To find out official attitudes towards SWHs and iii) To analyze determinants of household attitudes towards SWHs.
\end{abstract}

Data to address these objectives was generated using the mixed methods research design whereby both qualitative and quantitative data were gathered simultaneously to determine attitudes of both officials and the public towards domestic solar energy. A sample of $\mathbf{4 0 0}$ households consisting of low and highincome residential areas was selected using the Taro Yamane's formula, Old Naledi represented low income and Village represented high income. Approximately 264 households were interviewed in Old Naledi, and 136 in the Village. This was complemented by key informant interviews involving officials from the Department of Energy Affairs, Department of Environmental Affairs and distributors of SWHs involving solar power and solar hart. The key instrument for quantitative data collection was a semi-structured questionnaire, whereas interview guides were used to generate qualitative data. The key findings of the study are that that the public is aware of solar energy and its uses, and have a positive attitude towards its adoption in the form of SWHs on condition that they are reliable, cost effective and user friendly. Officials too had a positive attitude towards domestic solar energy but did not invest as much effort in promoting its adoption as they did in promoting conventional energy. The Government has taken good initiatives to promote solar energy, but they do not succeed due to apparent lack of commitment. The results of the study also show that SWHs are not adequately marketed by their distributors and this has contributed to the current adoption rate among the public.

In conclusion, the results of this study support the need for awareness building and capacity building from both the government officials and distributors of SWHs for the adoption of domestic solar energy to meet the escalating demands for energy in a manner that does not harm the environment. Based on these results, the study has made recommendations for policy, the public and future research.

Key words: Public, attitudes, solar energy, Solar Water Heaters, Gaborone, Botswana, environment, government officials, electricity, vendors

List of Abbreviations and Acronyms

SWHs Solar Water Heaters
BPC Botswana Power Corporation

MW Mega Watt

TWh Terawatt hour

\section{INTRODUCTION AND BACKGROUND}

\subsection{Introduction}

The study proposed to compare household attitudes towards the use of domestic solar energy, specifically Solar Water Heaters (SWHs), with those of officials. In this chapter, information about energy issues and challenges that have led to the need for the proposed study is provided. The aims and research questions are also provided to justify the purpose of the study.

\subsection{Background}

I E O (2019) predicted almost 50\% increase in global energy consumption by 2050, due to increased economic and population growth. However, due to Covid 19 restrictions the coal demand declined in 2020 by $4 \%$, for the first time since World War II. The same report showed that there is a rapid increase of $4.5 \%$ in coal demand as economic activities slowly recover.

The International Energy Agency (2010) reported world coal reserves of $1052 \mathrm{Bt}$ which could be used for 134.3 years at the current output. This report indicated insufficient coal reserves given the projected increase in energy demand and the dependence on coal as a source of energy. Carbon Brief (2020), reported over $40 \%$ of the world's electricity was generated by coal. Burning more coal to meet this demand emitted a lot of carbon dioxide, which was by far the most significant greenhouse gas that caused global warming.

All electricity used in Botswana was produced, transmitted and supplied by the Botswana Power Corporation (BPC). BPC owned and controlled Morupule Power Station, a coalfired and dry cooled power plant with an installed capacity of 132MW (4x33MW units). Population increase (based on the 2011 population census) and improved standard of living contributed to the increase in energy consumption in Botswana as reported by Reuters Staff (2020) Botswana Power Report (2012) predicted that the overall generation of power in Botswana between 2012 and 2017 would increase by an annual average of $57.77 \%$ to reach $5.58 \mathrm{TWh}$; net power 
consumption would grow from 3.55 TWh to 4.98TWh between the same years. The Statistics brief (2021) reported a $22.4 \%$ increase on the generation of electricity during the first quarter of 2012 as compared to a $14 \%$ increase reported during the first quarter of the previous year, 2020.

Botswana had not yet fully recovered from recession and therefore, the demand for electricity and increase in tariffs had the potential to push up inflation, which might result in the closure of some businesses, retrenchment of some workers due to loss of income and/or failure to make enough profit. Some businesses might also be forced by this increase to push their prices up. Foreigners might lose confidence in the country and move to countries that have lower energy costs. In addition, this might result in massive job losses and it might take a long time to recover and establish credibility among investors again and thus threatening Botswana's economic development. Larger electricity tariffs could automatically affect operational costs because almost all services are fully dependent on electricity.

Electricity consumption and demand continued to rise due to the government's intention to increase access to reliable and affordable energy services. This increase showed that consumption had doubled over the years and was already having an impact on the manufacturing industries, most of which were situated in Gaborone, as reported by the Statistics Botswana (2016). In order to meet the growing demand for energy, Gross (2020) reported that more coal was burnt and therefore more harmful gases, especially carbon dioxide, were released into the atmosphere, contributing to air pollution and eventually posing a further threat to global climate. To meet the growing demand for energy and reduce harmful air emissions, Gross (2020) further suggested switching to a cleaner energy system.

Belyakov (2019), the annual earth's solar resources were by far the largest whose potential is currently not being fully used. The solar systems were said to be cost effective, could be used together with other technologies and allowed for a cleaner environment according to Karatayev \& Clarke (2016). These studies implied that domestic solar systems could be used in an urban environment and were also proved to be an effective technology, which made them relevant for the city of Gaborone. Domestic solar energy could therefore be the ultimate solution to meet the growing electricity demand and to reduce carbon dioxide emissions for a greener environment.

The study compared public and official attitudes concerning renewable energy in general and domestic solar energy in particular. The Gaborone community was made up of consumers who were the major recipients of services; officials on the other side were the major decision makers and policy influencers. The majority of households in Gaborone used electrical appliances for their daily domestic activities. The study identified policies and practices, attitudes and behaviors that could have been facilitators of, or barriers to, the adoption of domestic solar energy systems. It also explained any differences in attitude between the officials and the community that might have existed.

\subsection{Statement of the Problem}

Rajamani (2021) reported that Botswana possessed plentiful renewable energy resources including, sunshine (over 3,200 hours/annum with a strength of 22 Mega Joules per hour), biogas ( 2.2 million cattle, $3 \mathrm{~kg}$ dung/cow/day) and fuel wood (200 tonnes/annum), with solar power (insulation) representing one of the strongest in the world. Although Botswana possessed plentiful renewable energy resources, it was largely dependent on non-renewable fossil fuels, coal being top on the list. The abundance of renewable energy resources did not correspond to their domestic usage level. To meet its growing demand for electricity, Botswana depended on imports instead of turning to the abundant local renewable energy resources.

IRP Report (2020 ) reported that the existing power plant had the capacity of $118 \mathrm{MW}$, which was far below the country's demand for electricity. Overall, about 70\% of energy resources were imported from South Africa and other Southern African countries. A maximum of 410 MW of electricity was imported from South Africa's Eskom. The contract with Eskom was discontinued by 2013 since Eskom had been unable to produce enough electricity to meet its own local demand. Botswana had since been experiencing load shedding as BPC was unable to generate enough electricity to compensate for declining imports. Moreri (2014) found out that a new agreement had been entered into with Eskom but it provided less power at a higher unit price and warned that it could cut the export completely if the situation in South Africa did not stabilize. BPC had to do away with its own load shedding schedule and resorted to large scale blackouts to address the situation. The wholesale blackouts affected retailers in major shopping malls, the companies that rented generators ran out of stock and those shops that could not hire some could not open for a full weekend.

Global Energy Review (2021) defined the efficiency of solar energy as using 'negawatts'; units of energy never used. There was a proposed expansion of Morupule Power Station, Morupule B instead of opting for the locally available solar energy in Botswana. Kedikilwe (2012) indicated that the 600 MW power plant was expected to enhance the social and economic wellbeing of all Batswana and stop imports by end of 2012 at an estimated cost of P11 billion. But according to Mokaila (2013), the plant had since experienced challenges and was not handed over in time which according to Pitse (2013) had also incurred extra costs leading to the possibilities of ceasing operations. The expansion cost a lot of money considering the fact that Botswana was a developing country. And yet the International Trade Administration (2021) has long argued that the increasing energy demands could be met by renewable solar energy which was environmentally friendly as compared to conventional energy sources. 
A larger power plant to meet the growing demands of energy meant burning more coal, which could lead ultimately to the depletion of this fossil fuel and an increase in the emission of pollutants and greenhouse gases such as carbon dioxide. It therefore became a problem when other possible sources of energy were not explored but rather a determination to embark on costly measures that were not environmentally friendly. Research was therefore needed to better understand how the public felt about domestic solar energy as an alternative to coal generated electricity and how this had influenced the adoption and use of solar power. This research therefore determined the attitudes and opinions of the public towards solar energy so as to find out how far they had been a barrier to, or facilitators of, the acceptance and use of solar power as an alternative source of energy. The study focused on Gaborone, Botswana's administrative and industrial capital, and on solar water heating, a major consumer of domestic energy. The researcher chose this topic in this particular area due to the minimal attention it had received from previous researchers.

\subsection{The Rationale/Need for the study}

Understanding the attitudes of the community and officials towards the use of domestic solar energy had contributed to thorough evaluation of efforts made to promote the use of solar energy in Gaborone and sound suggestions were considered. It gave the researcher a platform to recommend strategies to promote the use of locally available sources of energy to reduce dependence on imported energy sources and encouraged the use of renewable energy for environmental sustainability.

The current consumption of renewable energy in the area of study was $0.3 \%$ and the finding of this research identified attitudinal barriers to the adoption of solar power systems and provides useful data to inform the already existing plans to promote the use renewable energy and raise its contribution to the energy mix in the country.

The findings and recommendations of this study have contributed knowledge and identified areas, which require further research on the domestic consumption of solar energy, as well as information that could be used to inform future marketing strategies for solar power systems, such as SWHs.

\subsection{The Research Goal/Purpose}

The purpose of the study was to compare official and public attitudes towards domestic solar energy, with particular reference to the use of solar water heaters (SWHs). The unit of reference to represent the public was the household, whereas officials were key government decision-makers and implementers in the energy sector, including SWH vendors. Saleh, Haris \& Ahmed (2014) reported that solar energy systems could have noticeable socio-economic effects when accepted by householders. The (MMGE) Draft National Energy Policy (2016) showed that households demanded a lot of energy as compared to other sub-sectors such as transport, mining, government, trade and hotels and manufacturing in Botswana.

\subsubsection{Research Objectives:}

The following were the objectives of the proposed study:

1. To establish household perceptions and attitudes towards SWHs

2. To find out official attitudes towards SWHs

3. To analyze determinants of household attitudes towards SWHs

\section{LITERATURE REVIEW}

\subsection{Introduction}

This chapter reflects what other researchers had found out on the same topic and how relevant they are to the research. Factors that influence human behaviors and actions are explained in detail. An overview of previous studies on national and international energy policy adoption is also provided. The last part rates Africa's solar resources in relation to other regions in the world.

\subsection{Perceptions and Attitude Studies}

Azjen (1999) in the theory of planned behaviour found out that behaviours were influenced by the following three factors:

1. Attitude- the individual's evaluation of performing the behaviour

2. Perceived control- the perceived ease or difficulty of engaging in the behaviour

3. The subjective norm- the individual's perception of social pressure (related to behaviour)

According to Azjen (1999), people evaluated the outcomes of their behaviour in terms of importance, depending on how much the behaviour would affect the satisfaction of their need. If the use of coal generated electricity affected the needs of individuals largely, then they would adhere to measures available to satisfy their daily needs provided officials made them readily available to the public. Ritchie \& Roser (2020) suggested that energy consumers could choose on their own to use low carbon energy measures, but this would depend on national and international government policies.

Adams (2011) established that different countries had various reasons to implement policies for the adoption of SWHs depending on their local needs and circumstances. For example, use of renewable energy in Barbados was triggered by high energy prices; the United Kingdom promoted renewable energy policies as a response to the need to reduce greenhouse gas emissions; whereas in Austria tax incentives were used to encourage sustainable use of energy.

World Energy Outlook (2019) reported a $2.1 \%$ annual increase in electricity demand worldwide to 2040, especially in developing countries. It had been established that developing countries were the ones with high electricity demand due to growing population and the need to increase 
accessibility and improve the welfare of their citizens. Most developing countries such as Botswana, Namibia, Lesotho, Zimbabwe, and Swaziland were highly dependent on imports of electricity as their demand for electricity exceeded the amount of electricity generated locally.

These findings indicated that countries had different experiences that required action to promote renewable technologies. If there was negative attitude towards the use of domestic solar energy, positive attitudes could be triggered by realising the ultimate consequences of excessive coal burning and hence adopting solar energy as an alternative and a solution to the escalating energy demands.

Grantham (2012) concluded that the public was confused about how the human activities contributed to climate change; this was mainly because they neglected the fact that carbon dioxide was the key catalyst in global warming and was primarily produced when burning fossil fuels. Department of Energy \& Climate Change (2012) on the other hand, had demonstrated that the public often associated aerosols, insecticides, nuclear power generation and ozone depletion with climate change. Ajaps \& McLellan (2015) asserted that people could find it difficult to understand how their energy choices were harmful to the environment due to lack of environmental awareness and failure to associate the local environmental issues with the global. It was further reported by Boden et.al (2017) that the excessive generation of coal fired electricity accounted for $65 \%$ of total carbon dioxide emissions.

\subsection{Solar Energy Resources}

Figure 1 (Adams 2011) shows that Africa's solar resources were among the highest in the world, Botswana being among the countries with the highest potential. Africa Hub (2021) stated that Botswana had over 320 sunny days annually, with an average of $21 \mathrm{MJ} / \mathrm{m} 2$ global insulation per day with mean daily global radiation varying from $31 \mathrm{MJ} / \mathrm{m} 2$ in December to $16 \mathrm{MJ} / \mathrm{m} 2$ in June. This investigation confirmed that indeed Botswana had plenty of solar resources that remained unused despite the growing demand of energy.

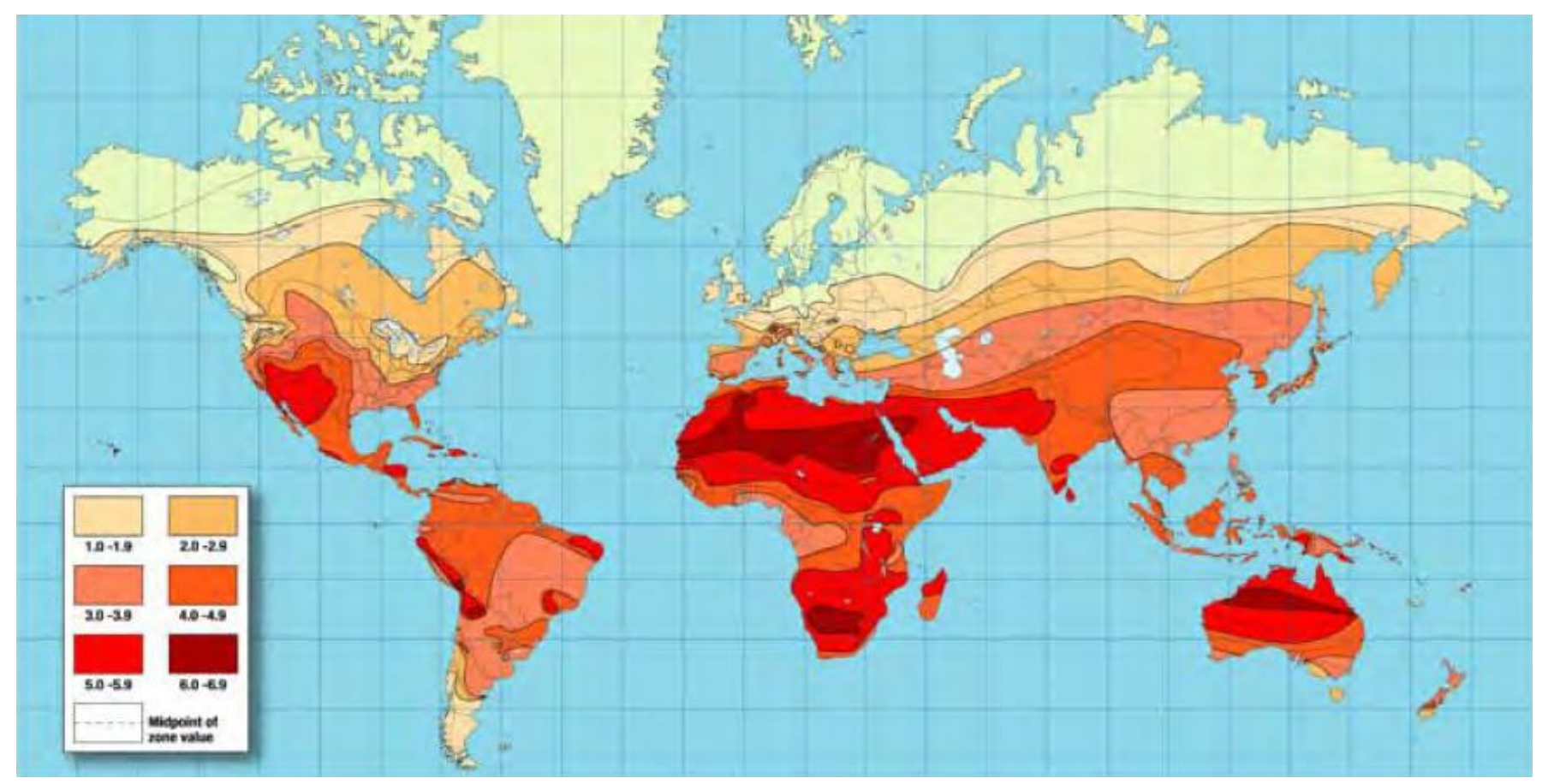

Figure 1 World Solar Radiation (Adams 2011, p.9)

\subsection{Barriers to the adoption of renewable energy resources}

Goldschmidt et. al. (2019) asserted lack of communication and validity as barriers to the adoption of photovoltaics (PVs). Consumers needed to hear constantly about the possible benefits of PVs from different distributors so that they could be in a position to make sound decisions when purchasing them. Public shows and exhibitions could be used to effectively pass the message on the use of PVs. Johan et. al. (2018) found product demonstration as an effective way of enabling consumers to have first-hand experience with the product and fully harness its validity and ability. According to
International Energy Agency (2019), consumers were not fully aware of available energy options and the environmental impacts of the electricity they were using. They did not have other alternatives since most of the times there was only one service provider and they did not have a choice but to purchase the same available product despite its harmful effects to the environment. In agreement with Beresford \& Sloper (2008), for the decision making process to effectively take place, there had to be different options for people to evaluate and make their own judgment. 
As stated by International Energy Agency (2019), early adopters of coal generated electricity seemed to have set a trend for the late adopters evidenced by constructors who were still building on the existing housing ideas instead of bringing in new technologies that support the installation of solar panels. Karakaya \& Sriwannawit (2015) argued that for people to adopt a new innovation they had to be fully aware of its advantages over another, they had to be attracted to it and then when they were fully convinced that the product could meet their ultimate expectation, that's when they could decide whether to reject or accept it. Furthermore, the same study found that for head of households to consider a new heating system, it had to be economic to continue the service and be reliable when compared to the old one. Karlstrøm \& Ryghaug ( 2014) asserted that the education system failed to respond quickly enough to meet emerging global issues and cater for new available technologies meant to mitigate such issues. This resulted in insufficient workforce skills and training as careers were not developed in technical skills required in solar energy systems.

As reported by Sæle \& Cherry (2017), PVs were too demanding : they were expensive, needed a lot of maintenance and were difficult to install. They did not add value to property and that did not make them a priority when building or renovating properties. Wyllie, Essah \& Ofetotse (2018) also found out that PVs were not easy to install and there were no trained installers; they were expensive to purchase and maintain and there were no financing options. They were not recommended by a lot of people and people did not own the buildings where solar water heaters could be installed. Department of Energy \& Climate Change (2012) discussed three factors that determined the adoption of a new technology such as SWH, the innovation should be user friendly; it should address the potential needs of consumers and should have a good reputation.

According to Kariuki (2018) there were no government laws and regulations to support the use of solar and other energy efficient technologies, available ones enhance conventional energy which made it difficult to establish innovative solar energy systems. Kannan \&Vakeesan (2016) reported that national policy on solar power could reduce carbon emissions at a national level and create employment opportunities in the manufacturing and engineering sectors and this would contribute to the nation's economic development as there will be an increase in local manpower.

From the literature it appeared that public misconception, confusion and neglect of clean energy sources were barriers to refraining from harmful practices whose ultimate result was global climate change. This study considered the fact that issues of global warming gained publicity over the years and they were still being preached and taught in schools in order to sensitise the youth and clear any misconceptions on the matter. The available literature did not compare the public and official attitudes towards the use of domestic solar energy in order to establish barriers to the adoption of this clean renewable source of energy, hence the need for the research.
Energy and Environment Partnership (2017), also discovered insufficient research on energy related issues in Botswana and the private sector not actively involved in the (renewable) energy sector. They also discovered that there was nothing in place to stimulate the connection between researchers and policy makers. Furthermore, previous researches focused mostly on the general perceptions of the community across and the barriers of solar energy adoption rather than comparing the perceptions of the community to those of major key players in the community.

\section{THE RESEARCH DESIGN AND METHODOLOGY}

\subsection{Introduction}

This chapter presents information on the approaches, methods and tools that were adopted for data collection, presentation and analysis. Insights are also given on how the participants were sampled in an unbiased way to ensure validity and reliability of the study. An ethical statement is included to explain how the rights of respondents were protected. A work plan of the proposed research was followed.

\subsection{Research Design}

The researcher adopted a mixed methods approach, using a triangulation type of research design to determine attitudes of both officials and the public towards domestic solar energy. Bulsara (2011) stated that triangulation ensures both qualitative and quantitative data are given equal attention for a deeper understanding of the issue. Qualitative and quantitative data were gathered simultaneously in this approach, but analyzed in different sections. The use of this technique also provided a clear picture of the topic by studying it from more than one perspective.

\subsubsection{Qualitative Research}

Qualitative research provided subjective data by establishing views, experiences and feelings of individuals or a set of people Bhandari (2020) which made it relevant for this study. The interview approach was adopted using key informant interviews (Appendices $9 \& 10$ ); this basically meant deriving data from a key stakeholder (e.g. relevant government official or SWH vendor) or a community member who was well informed on energy issues (e.g. a SWH adopter). These were the people who had the data relevant to the research.

\subsubsection{Quantitative Research}

Bhandari (2020) defined quantitative research as gathering numerical data and analyzing it statistically to describe and/or explain a given situation in a particular area. The study used a questionnaire based on a Likert type of scale where respondents were required to rate various statements (Appendix 7).

\subsection{Population, Sampling and Sample Size}

The Oxford English dictionary, edited by Hole and Hawker (2004), explained population as, 'the inhabitants of a place'. In research, a population is a grouping of individuals or 
elements, which would be the focus of a study. The population for this study was made up of households of the residents of Gaborone. The household was therefore the study is sampling unit.

Sampling on the other hand was regarded by Nastasi (n.d) as 'the selection of individuals, units, and/or settings to be studied'. To obtain valid findings, the researcher did not find it necessary to collect data from every household/member of the community and therefore purposive and random/systematic sampling techniques were used. The latter approach ensured that questionnaire respondents were picked in an unbiased manner to represent the population of households in Gaborone. Purposive sampling was used to pick key informants.

\subsubsection{Purposive Sampling}

According to McCombes S (2019) purposive sampling sought to identify respondents based on a carefully selected criterion. The researcher focused on people who had experience on energy related issues and insights on both renewable and non-renewable measures of generating electricity to meet the needs of the study. These were those who worked in the Department of Energy Affairs, BPC, Solar Hart (a solar power vendor) and its competitors. Residents of Gaborone known to have fully embraced (adopted) solar power for domestic purposes were also approached for key informant interviews.

\subsubsection{Systematic Sampling with a Random Start}

Household respondents were systematically selected based on their income status as indicated by their location in low and high cost residential areas. It was assumed that low and high income households were found in low cost and high cost residential areas, respectively. In his study of public attitudes towards environmental quality in Gaborone, Chanda (1999) reported that it was difficult to distinguish between medium and high income residential areas in Gaborone, as the two income categories tended to co-exist in residential areas. Thus, the study limited itself to one typical high income residential area and one typical low income location. In each study location, the first household was picked randomly, after which the rest were selected systematically using a predetermined sampling interval.

\subsubsection{Sample Size}

The sample size was calculated using Taro Yamane's formula. Yamane (1973) provided the following formula, where $\mathbf{n}$ was the sample size, $\mathbf{N}$ was the population size and $\mathbf{e}$ was the level of precision.

$$
n=\frac{N}{1+N(\boldsymbol{e})^{2}}
$$

Gaborone, the area of study, had a population of 233,135 with 73,834 households, according to the Central Statistics Office (2011). Therefore, using the household as the sampling unit and setting the sampling precision at five percent (i.e. e $=$ 0.05 ), the sample size for the study was 400 households, calculated as follows:

$$
\begin{aligned}
& =\frac{73834}{1+738340.052} 1+73834(0.0025)=184585+1= \\
& \left.\frac{73834}{185585}=397.8 \text { (Rounded off to } 400\right)
\end{aligned}
$$

This sample size was proportionately apportioned between low income and high income residential areas, where Old Naledi represented low income and Village represented high income. Central Statistics Office (2011) recorded a total population of 19,079 in Old Naledi and 12, 705 in Village and the proportional sub-sample sizes of the two were calculated as below:

Low Income population $($ Old Naledi $)=19079$

High Income population (Village) $=9705$

Total Sample population $=28784$

Thus, Old Naledi represented $66 \%$ and Village $34 \%$ of the sample population, respectively (Figure 2).

\section{Sample Population}

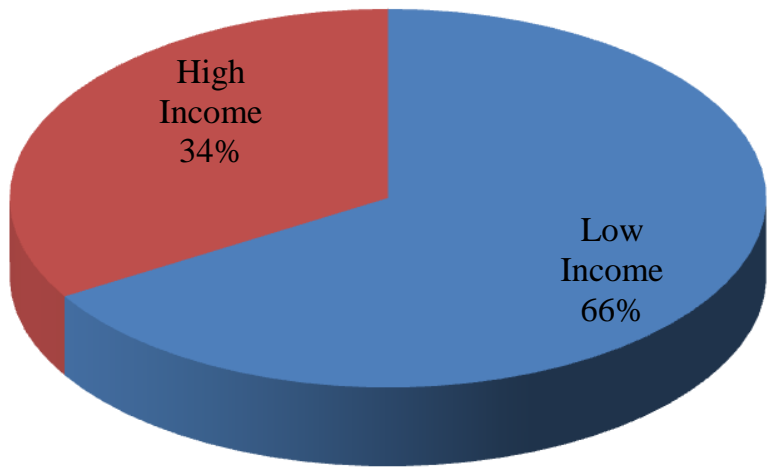

Figure 2 Sample Population

Based on these proportions, 264 households were interviewed in Old Naledi, and 136 in Village (see actual calculations below):

Low Income $\frac{66}{100} \times 400=264$ Households

High Income $\frac{34}{100} \times 400=136$ Households

\subsection{Data Collection Methods}

\section{i) Key Informant Interview Technique}

The key informant interview technique was adopted to obtain insights from people who were well informed about their community and had different backgrounds. Key informants according to Bhandari (2020) had a probability of providing 
relevant information and coming up with solutions and recommendations on the issue. An interview guide based on the research objectives and questions was used to ensure focus on issues relevant to the promotion and adoption of SWHs in Gaborone in particular and Botswana in general. A tape recorder was used to record the interviews and the researcher was able to probe their responses. The use of this instrument avoided instances where the researcher missed out on important points raised. The researcher did not intimidate the participants by scribbling time and again after a response. It also enabled the researcher to go over the recorded interviews at own time and analyzed data without missing any points.

\section{ii) Questionnaires}

A semi-structured questionnaire was used in the household survey of perceptions and attitudes towards SWHs. Respondents were asked the same questions in the same way. This method was effective in this study as most people were familiar with questionnaires, they were easy to administer, and analyze, and they were also cost effective and economic. The questionnaire consisted of two sections; Section A was on household demographic (socio-economic) profile (age of household head, gender, educational attainment, employment status, household income and household principal income source). Section B consisted of a set of closed-ended questions using a Likert scale to measure the respondents' level of agreement and disagreement for a series of statements. The questionnaire was interpreted in Setswana to assist those who did not understand English, especially those in the low income area. All respondents took part voluntarily and were free to withdraw if they so wished.

According to Kuhn (2020),Closed-ended questions were influential and easy to assess, questions or items were often repeated a couple of times to ensure reliability. Section B also contained open-ended questions to allow the respondent to provide a more complete or comprehensive response or to explain an answer to a closed-ended question. Thus, openended questions complemented closed-ended questions.

Previous research by McLeod (2019) had shown that attitudes concerning environmental issues could be measured by asking respondents to rate a sequence of related statements on a Likert type scale ranging from strongly agree to strongly disagree. A questionnaire employing the same type of statements determined the participants' perceptions towards domestic solar energy as an alternative to electricity generated using coal, a major source of greenhouse gases.

By mixing these two types of questions, the researcher gave respondents an opportunity to use their own words and provide definite answers with reasons. The questionnaire instrument was administered by the researcher herself to ensure accuracy of entries, to clarify questions, to answer queries from respondents and explain the purpose of the study.

\subsection{Data Analysis}

This means breaking down and evaluating the data obtained from the field in relation to the research objectives and questions. The following methods of data analysis were employed for qualitative and quantitative data.

\subsubsection{Qualitative Data}

Margaret (2019) suggested the content analysis approach when analyzing qualitative data gathered from any kind of interview. Content analysis involved coding and classifying data in order to highlight important findings of the study. Qualitative techniques mentioned above have been used to provide a clear description of quantitative data and hence the mixed methodology approach. Margaret (2019) further labelled this approach a significant enhancement of the validity of findings. The content was further analyzed at a manifest level which unfolded the attitudes of respondents on the problem area. The analyzed data was then used to complement quantitative data in the research.

\subsubsection{Quantitative Data}

Kaur et. al.(2018) stated that quantitative data could be analyzed using descriptive statistics to describe unprocessed data. Quantitative data was analyzed and interpreted using the SPSS program version 16.0.Measures of central tendency, specifically the mode and mean were adopted to determine the most frequent responses. Self-explanatory graphs, tables and pie charts had been used to present the processed data. Basic inferential statistics such as the Chi-Square, t-Test and simple correlation had been used to establish the relationship between demographic variables and attitudes and perceptions towards SWHs.

\subsection{Validity and Reliability}

Flake et. al. (2017). Explained validity in research as ensuring the research gave accurate intended outcomes. The researcher therefore ensured validity by engaging multiple methods such as open-ended and closed-ended questionnaires, key informant interviews and recording the interviews. Together, these rendered more valid and reliable data.

Flake et. al. (2017). Regarded reliability as the ability of the results to remain constant even when a different approach was adopted, i.e. different studies were able to replicate the results. To ensure reliability, the researcher had strictly followed the scientific approach to household sampling as outlined above. The research instruments have been appended to the study for reference by future researchers interested in investigating the same issue.

\subsection{Ethical Statement}

The researcher had adopted the three health care ethical principles Drysdale N 2021; Respect for persons, Beneficence, and Justice. The purposes of the study, its significance and outcomes were explained to the participants. It was explained to them that their participation was free and was not forced, and that they would not be penalized for not 
consenting to participate in the study. They were also assured that no information would be used about them without first obtaining their consent and they were protected from any harm or exploitation whatsoever.

An overview of the study was provided and permission was sought to record their views. Questionnaires had an accompanying cover letter (Appendix 6) which described the purpose of the questionnaire, requesting their response, the date the response was due and appreciation for the individual's consideration and time was also expressed. The same letter was also provided to the key informants (Appendix 8).

\section{DATA ANALYSIS AND DISCUSSION OF FINDINGS}

\subsection{Introduction}

This chapter analyzes, interprets and discusses the data generated by the study. The chapter is structured according to the themes suggested by the study's objectives presented in Chapter 1. Thus, it starts with results on household perceptions and attitudes towards SWHs, followed by results related to the official attitudes towards SWHs. The next section deals with results on the determinants of household attitudes towards SWHs, while the final section discusses the findings.

\subsection{Household Perceptions and Attitudes towards Solar Water Heaters (SWHs)}

Below are the findings regarding household characteristics and perceptions and attitudes towards the use of domestic energy, particularly SWHs.

\subsubsection{Respondents' Demographic Characteristics}

The demographical data generated included the respondents' age groups, gender, employment status, education levels, marital status and monthly incomes. This sub-section presents these characteristics which are later related to household perceptions and attitudes towards SWHs in sub-section 4.2.2. The distribution of demographic characteristics among income levels is shown in Appendix 1.

\subsubsection{Age Groups}

As indicated in Figure 3 below, among the respondents, $7.2 \%$ were less than 24 years old, $14.2 \%$ ranged from 25 to 29 in age, 27.2 were between 30 and 34 , and $51.2 \%$ were 35 years and older.

Eleven percent of heads of household in the low-income residential area were less than 24 years old and none of the same age was found in high income residential area. Heads of households between 25 and 29 years were predominantly the college going age and those who were still searching for jobs; they were also mostly found in the low income area $(17.4 \%)$ and a very few in the high income residential area (8.1\%).
The association between age of respondents and income level was statistically significant, $p$-value $<0.001$ (Chi-square $=25.174, \mathrm{df}=3$ ).

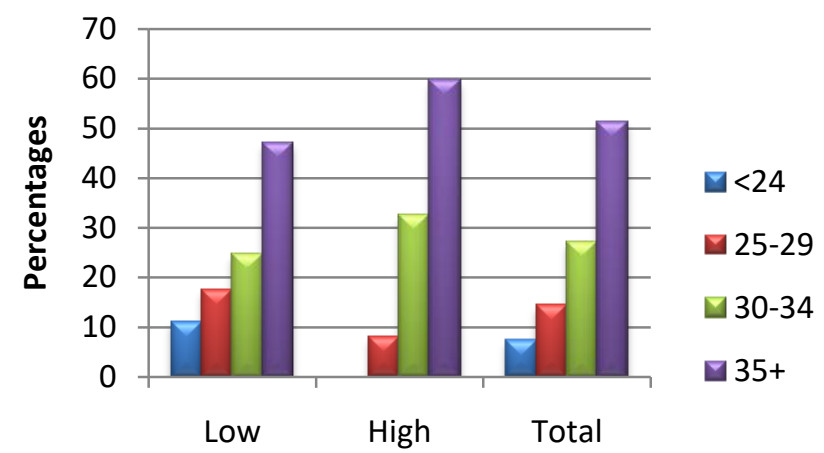

Income Levels

Source: Author-generated field data

\subsubsection{Gender}

According to Figure 4below, the majority of the respondents were females who made up $58.2 \%$ of the sample, as compared to males who on the other side made up the remaining $41.8 \%$.

Gender distribution according to the two income levels is shown in the same figure; there was no much difference between the number of male-headed households and femaleheaded households in both the low and high income residential areas. The percentages of female-headed households were almost equal between the low and highincome levels (Figure 4).

There was no statistical association between gender and income level since the $p$ value is 0.794 (Chi-square $=0.068$, $\mathrm{df}=1)$

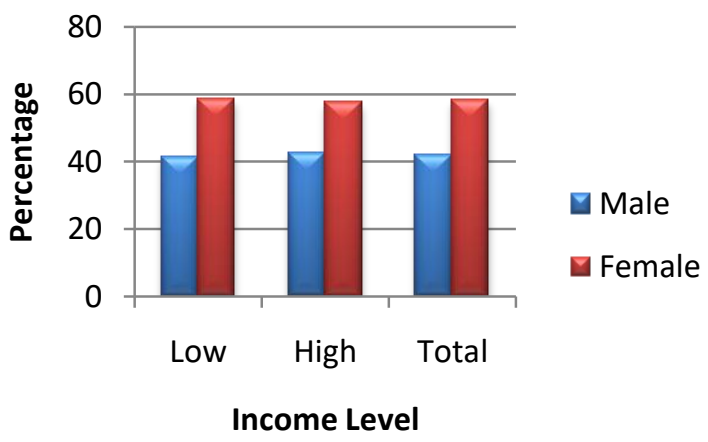

Figure 4 Gender of respondents

Source: Author-generated field data

\subsubsection{Employment Status}

Figure 5 below shows that $36.5 \%$ of the respondents were formally employed, $21.8 \%$ worked in the informal sector, $20 \%$ were unemployed and $21.8 \%$ were self-employed. 
Figure 5 further indicates that participants in high-income residential area were mostly employed in the formal sector (64\%), however there was a significant difference with low income residents who worked in the same sector $(22.3 \%)$. It further shows that a majority of heads of household in low income areas were either employed in the informal sector, unemployed or self-employed.

There was an association between employment status and income level since the $p$ value is $<0.001$, (Chi-square $=$ 72.126 , df $=3$ ).

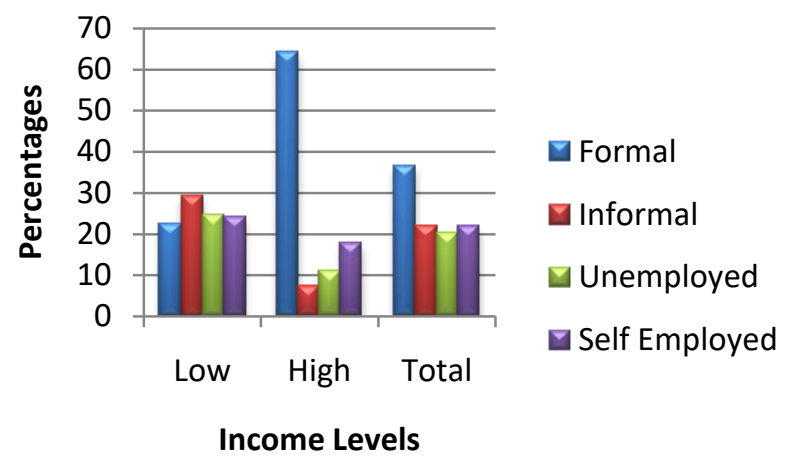

Figure 5 Employment status of participants

Source: Author-generated field data

\subsubsection{Education}

Among the respondents, $20.2 \%$ had obtained an elementary education level, $34.5 \%$ went up to BGSE, $4.2 \%$ had achieved a COSC and the majority had obtained a higher level of education and this made up $41.1 \%$ of the respondents. This is shown by Figure 6 below.

Heads of household in the low income residential area had not acquired a lot of education, $28.8 \%$ of them had obtained elementary qualifications and few (17\%)had gone up to tertiary level. On the other hand, a majority of high income residents $(87.5 \%)$ have acquired the highest level of education and only $3.7 \%$ had gone up to primary school.

There is an association between level of education acquired and income level, $\mathrm{p}$ value is $<0.001$, (Chi-square $=184.277$, $\mathrm{df}=3)$.

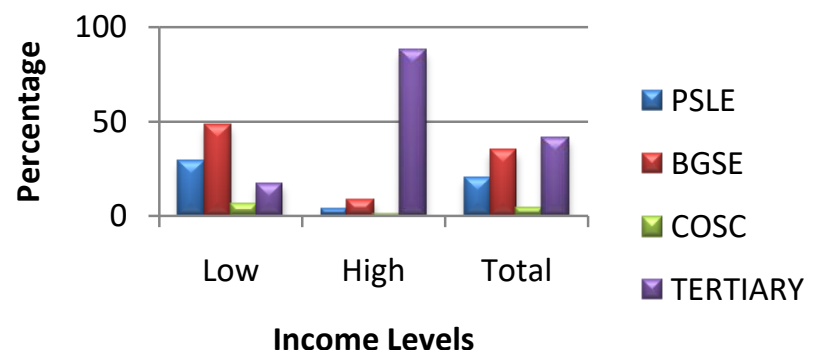

Figure 6 Education level of participants

Source: Author-generated field data

\subsubsection{Marital Status}

Figure 7 below indicates that three-quarters of the respondents (75\%) were single, $21.8 \%$ legally married, $2.2 \%$ divorced, $0.5 \%$ widowed and $0.5 \%$ separated from their spouses.

It further indicates that there was a high rate of single-headed households in low-income levels $(83.7 \%)$; the rate in high income levels was58.1percentage. Among the respondents in high-income level households, $36 \%$ were married and only $14.4 \%$ in low-income levels. There were slight differences between those divorced, widowed or separated from their spouses in the two income levels.

There was an association between marital status and income level, $\mathrm{p}$ value is $<0.001$, (Chi-square $=31.912, \mathrm{df}=4)$.

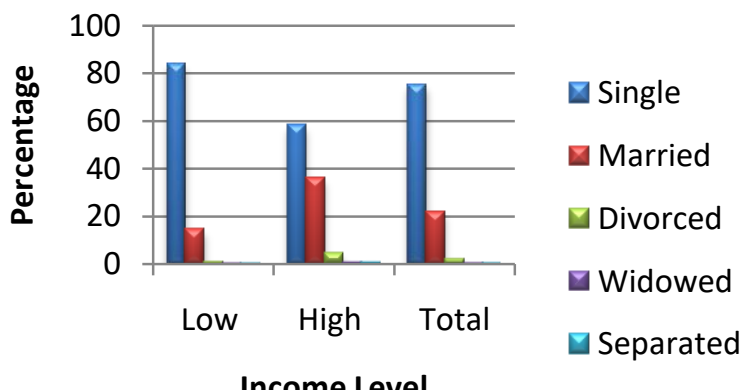

Figure 7 Marital status of participants

Source: Author-generated field data

\subsubsection{Monthly Income}

Figure 8 below indicates that the majority $(64.8 \%)$ of the respondents earned less than P2000; this included the 31\% who had no income at all as presented in Figure 8 below. Only $14.5 \%$ earned more than P10 000.

The majority of residents in the low-income area earned either low wages or they did not have wages at all. On the contrary, those in high-income level areas earned more.

There was an association between salaries and income level since $\mathrm{p}$ value is $<0.001$, (Chi-square $=227.520, \mathrm{df}=4$.

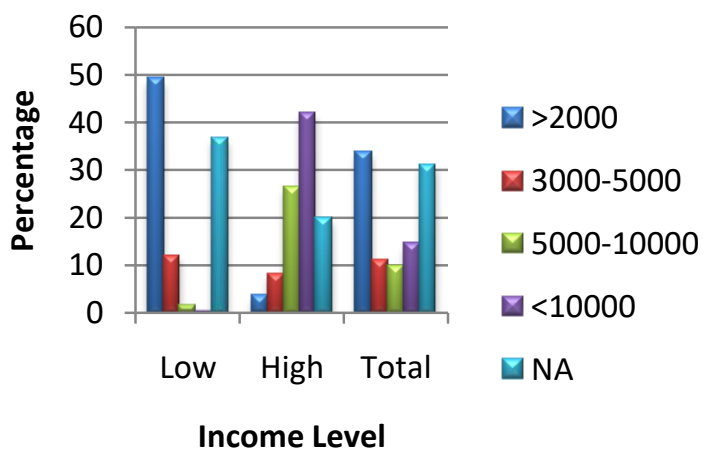

Figure 8 Participants' monthly income

Source: Author-generated field data 
As noted earlier, Appendix 1 presents a summary of the distribution of demographic characteristics according to income levels that have individually been discussed above.

\subsubsection{Household perceptions and attitudes towards SWHs}

\subsubsection{Environmental Awareness}

As indicated by Figure 9 below, $86 \%$ of the respondents knew something about solar energy while $14 \%$ did not know anything. This means many people were aware of solar energy and this could make it easier for teachings about the advantages and disadvantages of solar energy and coal generated electricity.

Comparing knowledge by residential area, Appendix 2 shows that a larger percentage $(92.6 \%)$ of the high income level households knew something about solar energy compared to $82.2 \%$ among the low income level households. This difference was statistically significant, $\mathrm{p}$-value $=0.017$ (Chisquare $=8.16, \mathrm{df}=1$ ).

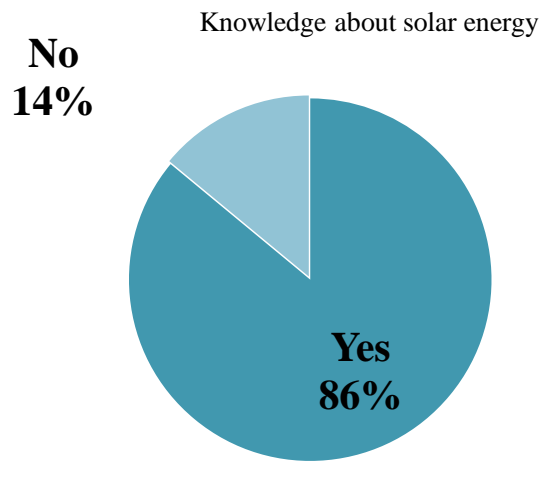

Figure 9 The proportion of respondents who knew something about solar Source: Author-generated field data energy

Table 1 below indicates that the respondents who knew something on solar energy were the ones who attained a higher level of education. The majority of the respondents had knowledge about solar energy. The lowest percentage (75.3\%) among the primary school had knowledge about solar energy and $95.7 \%$ of the tertiary had knowledge on solar energy.

The association between educational status and knowledge about solar energy was statistically significant, $\mathrm{p}$-value $<0.001$ $($ Chi-square $=26.834, \mathrm{df}=6)$.

\begin{tabular}{|c|c|c|c|c|c|c|c|c|c|}
\hline \multicolumn{8}{|c|}{$\begin{array}{l}\text { Table } 1 \text { Knowledge on solar energy according to Education } \\
\text { Status }\end{array}$} & & \\
\hline & & & \multicolumn{4}{|c|}{ Education Status } & \multirow{2}{*}{$\begin{array}{l}\text { Tot } \\
\text { al }\end{array}$} & \multirow[b]{2}{*}{$\begin{array}{l}\mathrm{p}- \\
\text { valu } \\
\mathrm{e} \\
\end{array}$} & \multirow[b]{2}{*}{$\begin{array}{l}\text { Chi- } \\
\text { square } \\
\text { (df) }\end{array}$} \\
\hline & & & $\begin{array}{l}\text { PS } \\
\text { LE }\end{array}$ & $\begin{array}{l}\text { BG } \\
\text { SE }\end{array}$ & $\begin{array}{l}\mathrm{CO} \\
\mathrm{SC}\end{array}$ & $\begin{array}{l}\text { Terti } \\
\text { ary }\end{array}$ & & & \\
\hline $\begin{array}{l}\text { Do } \\
\text { you }\end{array}$ & $\begin{array}{l}\text { Y } \\
\text { es }\end{array}$ & $\begin{array}{l}\text { Cou } \\
\text { nt }\end{array}$ & 61 & 111 & 14 & 157 & 343 & $\begin{array}{l}<0.0 \\
01\end{array}$ & $\begin{array}{l}26.834 \\
(6)\end{array}$ \\
\hline
\end{tabular}

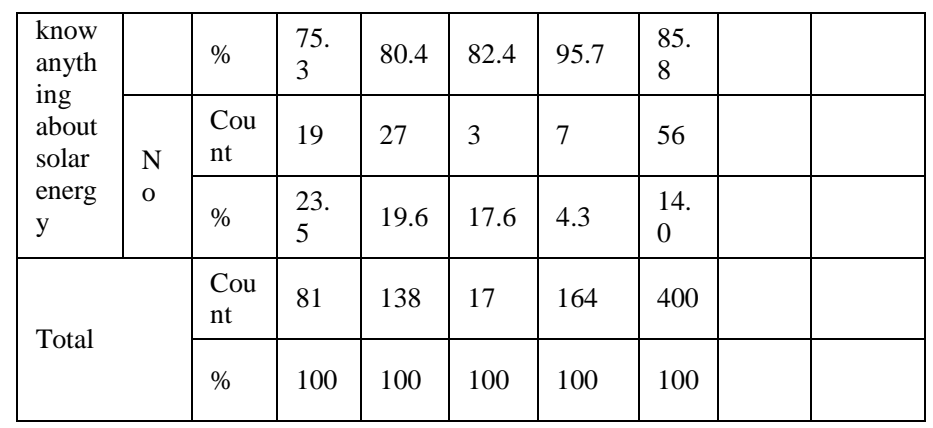

Source: Author-generated field data

\subsubsection{Uses of Solar Energy}

Figure 10 shows that more than half (61\%)of the respondents knew that solar energy could be used for heating water, $24 \%$ knew that it could be used for electric appliances, $14 \%$ for lighting and only $1 \%$ stated that it could be used for cooking. This indicated that the majority of people living in Gaborone knew that solar energy could be used for water heating purposes.

As indicated in Appendix 2, a high percentage, $82.4 \%$, of the high-income level residents mentioned that solar energy could be used for water heating purposes, compared to less than half, $40.9 \%$, of the low income residents. It was also found out that $14.4 \%$ of the low income residents did not know anything on what solar energy could be used for as compared to only $1.5 \%$ of the high income level residents.

The data showed a significant association between the knowledge of solar energy use and income level, $\mathrm{p}$ value $=$ $<0.001$ (Chi-square $=66.06, \mathrm{df}=4)$.

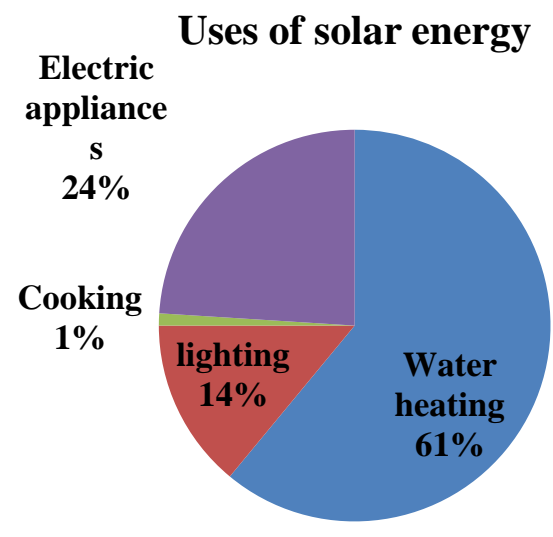

Figure 10 Respondents' knowledge of the uses of solar energy Source: Author-generated field data

\subsubsection{Awareness of environmental terms}

The respondents were given a list of environmental terms from which to choose only one they were familiar with. Of the 400 respondents, $73 \%$ were aware of the term drought, they had either heard about it or read about it and some reported that they had experienced the phenomenon, 16\% had heard 
more about climate change, $1 \%$ about renewable energy, $6 \%$ about solar power and $4 \%$ had heard nothing on these terms. Figure 11 below presents this:

\section{Awareness of environmental terms}

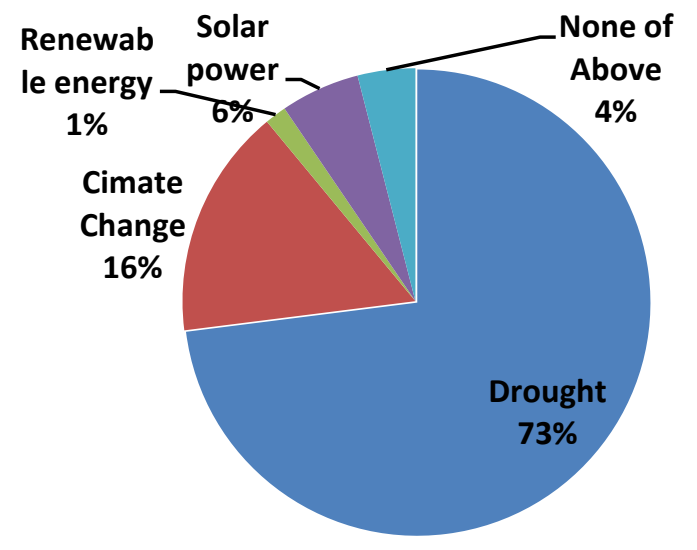

Figure 11 Environmental terms that respondents were aware of Source: Author-generated field data

\subsubsection{Respondents' Sources of information about environmental terms}

As indicated by Table 4 below, the majority of participants who were aware of the term solar power learnt about it from school. Most of them heard about climate change from radio stations. Participants heard about renewable energy from schools and radio while solar power was heard mostly from educational institutions.

The largest percentage $(32.8 \%)$ of information about climate change was obtained from radio, whereas for the other items the main source of information came from educational institutions, followed by radio.

Appendix 2 illustrates that among the given environmental terms, climate change showed a large difference between the two income levels. About $22 \%$ of the high-income levels were aware of climate change, whereas only $12.9 \%$ of the low income were aware of the same term.

The analysis further indicated a significant association between source of information and awareness of environmental terms, p-value $<0.001$ (Chi-square $=226.331, \mathrm{df}=28$ ). The majority of respondents heard about environmental terms, particularly drought and solar energy from educational institutions whereas a few heard about environmental terms from reading newspapers and the internet.

\begin{tabular}{|c|c|c|c|c|c|c|c|c|c|c|}
\hline \multicolumn{11}{|c|}{$\begin{array}{c}\begin{array}{c}\text { Table } 2 \text { Numbers and percentages of awareness of environmental terms by source of } \\
\text { Information }\end{array} \\
\text {. }\end{array}$} \\
\hline \multirow{2}{*}{\multicolumn{2}{|c|}{ Environmental Terms }} & \multicolumn{8}{|c|}{ Where did you learn terms from? } & \multirow{3}{*}{$\begin{array}{r}\text { Total } \\
292 \\
\end{array}$} \\
\hline & & \multirow{2}{*}{$\begin{array}{c}\begin{array}{c}\text { Educational } \\
\text { Institutions }\end{array} \\
100\end{array}$} & \multirow{2}{*}{$\begin{array}{c}\begin{array}{c}\text { Books and } \\
\text { pamphlets }\end{array} \\
10\end{array}$} & \multirow{2}{*}{$\begin{array}{c}\mathrm{TV} \\
59\end{array}$} & \multirow{2}{*}{$\begin{array}{c}\text { Newspaper } \\
13\end{array}$} & \multirow{2}{*}{$\frac{\text { Radio }}{56}$} & \multirow{2}{*}{$\frac{\text { Internet }}{4}$} & \multirow{2}{*}{$\begin{array}{c}\begin{array}{c}\text { Word of } \\
\text { Mouth }\end{array} \\
38\end{array}$} & \multirow{2}{*}{$\begin{array}{c}\text { Other } \\
12\end{array}$} & \\
\hline Drou & $\mathrm{N}$ & & & & & & & & & \\
\hline Drougnt & $\%$ & 34.2 & 3.4 & 20.2 & 4.5 & 19.2 & 1.4 & 13.0 & 4.1 & 100.0 \\
\hline \multirow{2}{*}{$\begin{array}{l}\text { Cimate } \\
\text { Change }\end{array}$} & $\mathrm{N}$ & 17 & 5 & 8 & 3 & 21 & 2 & 8 & 0 & 64 \\
\hline & $\%$ & 26.6 & 7.8 & 12.5 & 4.7 & 32.8 & 3.1 & 12.5 & 0.0 & 100.0 \\
\hline \multirow{2}{*}{$\begin{array}{c}\text { Renewable } \\
\text { energy }\end{array}$} & $\mathrm{N}$ & 2 & 1 & 0 & 0 & 2 & 0 & 0 & 1 & 6 \\
\hline & $\%$ & 33.3 & 16.7 & 0.0 & 0.0 & 33.3 & 0.0 & 0.0 & 16.7 & 100.0 \\
\hline \multirow{2}{*}{ Solar energy } & $\mathrm{N}$ & 8 & 2 & 3 & 1 & 4 & 1 & 2 & 1 & 22 \\
\hline & $\%$ & 36.4 & 9.1 & 13.6 & 4.5 & 18.2 & 4.5 & 9.1 & 4.5 & 100.0 \\
\hline \multirow{2}{*}{$\begin{array}{c}\text { None of } \\
\text { Above }\end{array}$} & $\mathrm{N}$ & 0 & 0 & 0 & 0 & 0 & 0 & 0 & 16 & 16 \\
\hline & $\%$ & 0.0 & 0.0 & 0.0 & 0.0 & 0.0 & 0.0 & 0.0 & 100.0 & 100.0 \\
\hline \multirow{2}{*}{ Total } & $\mathrm{N}$ & 127 & 18 & 70 & 17 & 83 & 7 & 48 & 30 & 400 \\
\hline & $\%$ & 31.8 & 4.5 & 17.5 & 4.3 & 20.8 & 1.8 & 12.0 & 7.5 & 100.0 \\
\hline
\end{tabular}

Source: Author-generated field data

The participants were given a list of energy sources to identify which ones are harmful to the environment when used to generate electricity. The majority of the people according to Figure 12, identified coal to be more harmful (48\%), followed by diesel $(40 \%)$, then wind $(2 \%)$ and solar at only $1 \%$. The majority of the respondents were aware of the dangers of coal, the reasons given about it and diesel is that when they were burnt they emitted harmful gases, which were not good for their health. If a lot of people understood the dangers of coal and diesel to their health, then it meant they would not accept their use for generating electricity if they had a choice. 
Which of the following are harmful to the environment when used to produce electricity?

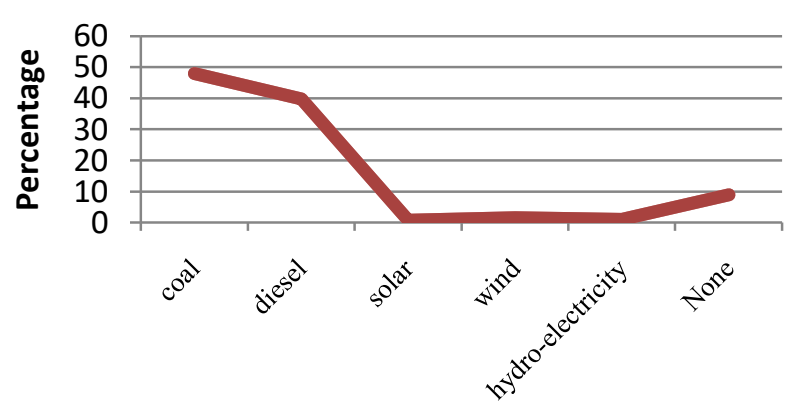

Figure 12 Energy sources that are harmful to the environment Source: Author-generated field data

According to Table 3 below, there was a significant association between perception of environmental harm and income level of respondents, value $=<0.001$ (Chi-square $=$ 21.057 , df =5). The majority of respondents who perceived coal as harmful to the environment when used to generate coal were found in high-income level households.

\begin{tabular}{|c|c|c|c|c|c|c|c|}
\hline \multicolumn{6}{|c|}{ Table 3 Perception of environmental harm according to Income Level of respondents } & & \\
\hline & & & \multicolumn{2}{|c|}{$\begin{array}{c}\text { Income Level of } \\
\text { respondent }\end{array}$} & \multirow{2}{*}{ Total } & \multirow[b]{2}{*}{ p-value } & \multirow[b]{2}{*}{$\begin{array}{l}\text { Chi-square } \\
(\mathrm{df})\end{array}$} \\
\hline & & & $\begin{array}{l}\text { Low } \\
\text { Income }\end{array}$ & $\begin{array}{l}\text { High } \\
\text { Income }\end{array}$ & & & \\
\hline \multirow{12}{*}{$\begin{array}{c}\text { Perception of } \\
\text { environmental } \\
\text { harm. }\end{array}$} & \multirow[b]{2}{*}{ coal } & Count & 114 & 78 & 192 & $<0.001$ & $21.057(5)$ \\
\hline & & $\begin{array}{c}\% \text { within Income Level of } \\
\text { respondent }\end{array}$ & $43.2 \%$ & $57.4 \%$ & $48.0 \%$ & & \\
\hline & \multirow[b]{2}{*}{ diesel } & Count & 106 & 53 & 159 & & \\
\hline & & $\begin{array}{c}\% \text { within Income Level of } \\
\text { respondent }\end{array}$ & $40.2 \%$ & $39.0 \%$ & $39.8 \%$ & & \\
\hline & \multirow[b]{2}{*}{ solar } & Count & 1 & 2 & 3 & & \\
\hline & & $\begin{array}{c}\% \text { within Income Level of } \\
\text { respondent }\end{array}$ & $0.4 \%$ & $1.5 \%$ & $0.8 \%$ & & \\
\hline & \multirow[b]{2}{*}{ wind } & Count & 5 & 1 & 6 & & \\
\hline & & $\begin{array}{c}\% \text { within Income Level of } \\
\text { respondent }\end{array}$ & $1.9 \%$ & $0.7 \%$ & $1.5 \%$ & & \\
\hline & \multirow[b]{2}{*}{$\begin{array}{l}\text { hydro- } \\
\text { electricity }\end{array}$} & Count & 4 & 0 & 4 & & \\
\hline & & $\begin{array}{l}\% \text { within Income Level of } \\
\text { respondent }\end{array}$ & $1.5 \%$ & $0.0 \%$ & $1.0 \%$ & & \\
\hline & \multirow[b]{2}{*}{ None } & Count & 34 & 2 & 36 & & \\
\hline & & $\begin{array}{c}\% \text { within Income Level of } \\
\text { respondent }\end{array}$ & $12.9 \%$ & $1.5 \%$ & $9.0 \%$ & & \\
\hline \multirow{2}{*}{\multicolumn{2}{|c|}{ Total }} & Count & 264 & 136 & 400 & & \\
\hline & & $\begin{array}{c}\% \text { within Income Level of } \\
\text { respondent }\end{array}$ & $100.0 \%$ & $100.0 \%$ & $100.0 \%$ & & \\
\hline
\end{tabular}

Source: Author-generated field data

Table 4 below shows various items, which measured perceptions about SWHs. Agree and strongly agree responses on each item were combined into agree. Overall, the majority, around $90 \%$, of the respondents agreed that information on SWHs was not readily available to the public, burning Table 4 Perceptions measured on a Likert Scale by income levels excessive coal contributed to climate change and that the government was not doing enough to promote SWHs. Perceptions on almost all items were more or less similar between the two income levels, which means they had similar views on most statements.

\begin{tabular}{|c|c|c|c|c|c|c|}
\hline & \multicolumn{6}{|c|}{ Income Level of respondent } \\
\hline & \multicolumn{2}{|c|}{ Low Income } & \multicolumn{2}{|c|}{ High Income } & \multicolumn{2}{|c|}{ Total } \\
\hline & Count & $\%$ & Count & $\%$ & Count & $\%$ \\
\hline Perceptions And Awareness & & & & & & \\
\hline $\begin{array}{c}\text { SWHs are not marketed enough by their } \\
\text { distributors. Agree Disagree }\end{array}$ & 246 & 93.2 & 108 & 79.4 & 354 & 88.5 \\
\hline $\begin{array}{c}\text { Burning excessive coal will contribute to climate } \\
\text { change in Botswana. Agree Disagree }\end{array}$ & 239 & 90.5 & 128 & 94.1 & 367 & 91.8 \\
\hline
\end{tabular}




\begin{tabular}{|c|c|c|c|c|c|c|c|}
\hline Using SWHs is pollution free.Agree Disagree & & 250 & 94.7 & 130 & 95.6 & 380 & 95.0 \\
\cline { 1 - 6 } $\begin{array}{c}\text { Neglecting greener energy alternatives causes } \\
\text { global warming. Agree Disagree }\end{array}$ & & 223 & 84.5 & 121 & 89.0 & 344 & 86.0 \\
\cline { 1 - 6 } $\begin{array}{c}\text { Government does not give SWHs more popularity } \\
\text { than electricity. Agree Disagree }\end{array}$ & 243 & 92.0 & 100 & 73.5 & 343 & 85.8 \\
\hline
\end{tabular}

Source: Author-generated field data

\subsubsection{Attitudes towards SWHs}

The main question item to address attitudes towards the use of SWHs or any other energy type was "Would you consider using SWHs". Normally users of any item tend to have positive attitude towards the item. Some people might have positive attitude towards a product and yet not consider using the product for various reasons, like cost or lack of compatibility with their existing housing facilities. Also, people might not use SWHs since the houses they are living in were rented and not owned by them.

Table 5 shows the distribution of respondents who would consider using SWHs by various categories of the respondents. Overall, $86.2 \%$ of the respondents would consider using SWHs, hence had positive attitude towards SWHs. More than $75 \%$ of the respondents who used gas and paraffin, and even a higher percentage, $90.4 \%$, of the respondents who used coal-generated electricity, would consider using SWHs. The association between energy used and attitude was significant, $\mathrm{p}$-value $=0.054$, ChiSquare $=12.393, \mathrm{df}=6$ )

\begin{tabular}{|c|c|c|c|c|c|}
\hline \multicolumn{4}{|c|}{$\begin{array}{c}\text { Table } 5 \text { Attitudes towards usage of SWHs by } \\
\text { Selected potential determinants }\end{array}$} & & \\
\hline & & \multicolumn{2}{|c|}{$\begin{array}{c}\text { Would you } \\
\text { consider using } \\
\text { it? }\end{array}$} & & \\
\hline & & \multicolumn{2}{|c|}{ Yes } & & \\
\hline & & $\mathrm{N}$ & $\%$ & $\begin{array}{l}\text { Chi- } \\
\text { square } \\
\text { (df) }\end{array}$ & $\begin{array}{c}\mathrm{p}- \\
\text { value }\end{array}$ \\
\hline \multirow{9}{*}{$\begin{array}{c}\text { What type of } \\
\text { energy do you } \\
\text { use? }\end{array}$} & Coal & 197 & 90.4 & $12.393(6)$ & 0.054 \\
\hline & $\begin{array}{c}\text { Diesel/ } \\
\text { petroleum }\end{array}$ & 3 & 100.0 & & \\
\hline & Solar & 2 & 100.0 & & \\
\hline & Wind & 0 & 0.0 & & \\
\hline & $\begin{array}{l}\text { Hydro- } \\
\text { electricity }\end{array}$ & 24 & 92.3 & & \\
\hline & $\begin{array}{l}\text { None of } \\
\text { Above }\end{array}$ & 16 & 84.2 & & \\
\hline & Gas & 63 & 78.8 & & \\
\hline & Paraffin & 40 & 76.9 & & \\
\hline & Total & 345 & 86.2 & & \\
\hline \multirow{3}{*}{$\begin{array}{l}\text { Income Level } \\
\text { of respondent }\end{array}$} & $\begin{array}{l}\text { Low } \\
\text { Income }\end{array}$ & 221 & 83.7 & $4.217(1)$ & 0.040 \\
\hline & $\begin{array}{l}\text { High } \\
\text { Income }\end{array}$ & 124 & 91.2 & & \\
\hline & Total & 345 & 86.2 & & \\
\hline Education & PSLE & 63 & 77.8 & $11.402(3)$ & 0.010 \\
\hline
\end{tabular}

\begin{tabular}{|c|c|c|c|l|l|}
\hline Status & BGSE & 116 & 84.1 & & \\
\cline { 2 - 6 } & COSC & 14 & 82.4 & & \\
\hline & Tertiary & 152 & 92.7 & & \\
\hline & Total & 345 & 86.2 & & \\
\hline
\end{tabular}

Source: Author-generated field data

Figure 13 illustrates that the majority of respondents, 54\%, used coal-fired electricity to heat water, but a number of them did not know that the electricity they used was generated from burning coal (this made up the 7\% of those who responded that they used hydro-electricity and probably the $1 \%$ of diesel/petroleum and solar). Among the respondents, $13 \%$ used paraffin bought from petrol stations, 20\% used gas stoves for water heating. Some of the respondents who used electricity to heat water had gas stoves as a backup and some to reduce the high costs of electricity bills since they had noticed that geysers were high-energy consumers.

Types of energy used to heat water

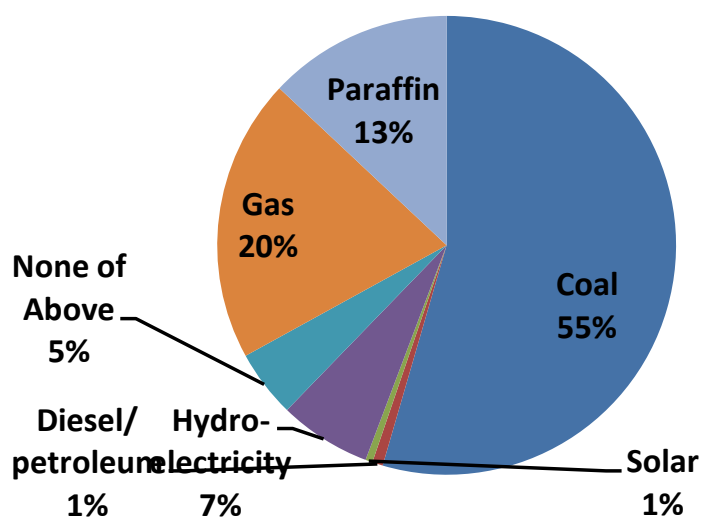

Figure 13 Energy type used by respondents to heat water

Source: Author-generated field data

Table 6 below shows that about 218 households used coal generated electricity to heat water despite their monthly income. Only two households used solar energy for the same purpose. Gas and paraffin were also used to save electricity. The table further showed that the type of energy used was significantly influenced by monthly earnings, $\mathrm{p}$-value = $<0.001$ (Chi-square $=112, \mathrm{df}=24)$. Generally, those people who earned low income preferred using more affordable sources of energy such as gas and paraffin. 
Table 6: Relationship between income and energy used to heat water

\begin{tabular}{|c|c|c|c|c|c|c|c|c|c|c|c|}
\hline \multirow[b]{2}{*}{$\begin{array}{l}\text { Monthly } \\
\text { Income }\end{array}$} & & \multicolumn{7}{|c|}{ What type of energy do you use to heat water? } & \multirow[b]{2}{*}{ Total } & \multirow[b]{2}{*}{ p-value } & \multirow[b]{2}{*}{$\begin{array}{c}\text { Chi-square } \\
\text { (df) }\end{array}$} \\
\hline & & $\begin{array}{c}\text { Coal- } \\
\text { generated } \\
\text { electricity }\end{array}$ & $\begin{array}{c}\text { Diesel/ } \\
\text { petroleum }\end{array}$ & Solar & $\begin{array}{l}\text { Hydro- } \\
\text { electricity }\end{array}$ & $\begin{array}{c}\text { None of } \\
\text { Above }\end{array}$ & $\begin{array}{c}\mathrm{Ga} \\
\mathrm{s}\end{array}$ & Paraffin & & & \\
\hline & $<2000$ & 54 & 1 & 2 & 1 & 10 & 39 & 28 & 135 & $<0.001$ & 1.123E2(24) \\
\hline & $3000-5000$ & 25 & 0 & 0 & 4 & 3 & 9 & 2 & 43 & & \\
\hline & $5000-10000$ & 25 & 0 & 0 & 11 & 0 & 2 & 2 & 40 & & \\
\hline & $>10000$ & 48 & 2 & 0 & 7 & 0 & 1 & 0 & 58 & & \\
\hline & No salary & 66 & 0 & 0 & 3 & 6 & 29 & 20 & 124 & & \\
\hline \multicolumn{2}{|c|}{ Total } & 218 & 3 & 2 & 26 & 19 & 80 & 52 & 400 & & \\
\hline
\end{tabular}

Source: Author-generated field data

According to Figure 14, 86\% of the respondents would use SWHs provided they were affordable and easy to use. The $14 \%$ of respondents in Figure 9above who said they did not know much about solar energy were probably among the $14 \%$ who would not consider using it because they had never seen it used anywhere. Of the $86 \%$ who said they would use it explained that it was less risky and cheaper to use. On the other hand, the reasons that were given for not using SWHs were that they did not know about it, they had not seen it effectively used in their surroundings and they have heard that it was very expensive to install its equipment.

\section{Would you use SWHs?}

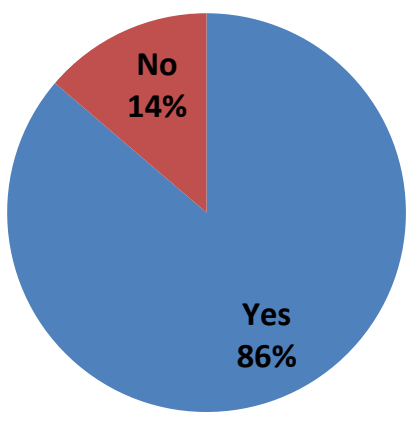

Figure 14 Respondents' attitude towards the use of SWHs

Source: Author-generated field data

Table 7 indicated that the majority of heads of household in both low and high-income levels would consider using SWHs provided they were reliable, affordable, user friendly and durable. There was an association between attitudes towards using SWHs and income level, p-value $=0.040$, (Chi-square $=$ 4.217, $\mathrm{df}=1$ ). This meant that people of the two income levels had a positive attitude towards the use of domestic solar energy, SWHs in particular, but conditionally so.
Table 7: Respondents attitudes towards using SWHs according to income level

\begin{tabular}{|c|c|c|c|c|c|c|c|}
\hline & & \multicolumn{5}{|c|}{$\begin{array}{c}\text { Income Level of } \\
\text { respondent }\end{array}$} & \multicolumn{2}{|c|}{} \\
\hline & & \multicolumn{2}{|c|}{$\begin{array}{c}\text { Low } \\
\text { Income }\end{array}$} & \multicolumn{2}{c|}{$\begin{array}{c}\text { High } \\
\text { Income }\end{array}$} & \multicolumn{2}{c|}{} \\
\hline & & $\mathrm{N}$ & $\%$ & $\mathrm{~N}$ & $\%$ & $\begin{array}{c}\text { p- } \\
\text { value }\end{array}$ & $\begin{array}{c}\text { Chi- } \\
\text { square } \\
\text { (df) }\end{array}$ \\
\hline $\begin{array}{c}\text { Would u } \\
\text { consider } \\
\text { using } \\
\text { SWHs? }\end{array}$ & Yes & 221 & 64.1 & 124 & 35.9 & 0.040 & $4.217(1)$ \\
\cline { 2 - 8 } & No & 43 & 78.2 & 12 & 21.8 & & \\
\hline
\end{tabular}

Source: Author-generated field data

Figure 15 below showed that $4.5 \%$ of the respondents were not at all concerned that the country's climate and long-term weather patterns were changing, whereas $8 \%$ were a little concerned. Some of their reasons were that even if they could be concerned there was nothing they could do about it since it is something that was bound to happen and they did not have control over it. They also blamed developed countries for industrialisation. The $29 \%$ and $58.5 \%$ who were concerned and very concerned, respectively, stressed that there was low food production due to low rainfall, excessive heat affected daily activities leading to low production especially in the workplace and that they were forced by this situation to buy food which was expensive and unaffordable to some low income residents.

Concerns about changing weather patterns

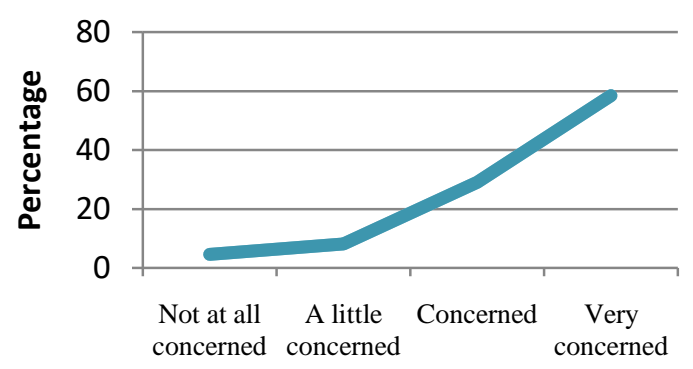

Figure 15 Respondents' concerns about changing weather patterns Source: Author-generated field data 
Table 8 showed that most of the concern about changing weather patterns was coming from the low-income households with low levels of education. However, the percentage of those respondents who were not at all concerned about the changing weather patterns was low in high-income level households and slightly high in low-income levels. This could imply that many people were concerned about the long-term changes in weather patterns despite their education and income levels because they were all experiencing the consequences of global warming.

Table 1 Participants' attitudes towards changing weather patterns according to education and income levels

\begin{tabular}{|c|c|c|c|c|c|c|c|c|c|c|}
\hline & & & \multicolumn{8}{|c|}{ Income Level of respondent } \\
\hline & & & \multicolumn{4}{|c|}{ Low Income } & \multicolumn{4}{|c|}{ High Income } \\
\hline & & & \multicolumn{4}{|c|}{ Education Status } & \multicolumn{4}{|c|}{ Education Status } \\
\hline & & & $\begin{array}{l}\text { PS } \\
\text { LE }\end{array}$ & $\begin{array}{l}\text { BG } \\
\text { SE }\end{array}$ & $\begin{array}{l}\mathrm{CO} \\
\mathrm{SC}\end{array}$ & $\begin{array}{l}\text { Tert } \\
\text { iary }\end{array}$ & $\begin{array}{l}\text { PS } \\
\text { LE }\end{array}$ & $\begin{array}{l}\text { BG } \\
\text { SE }\end{array}$ & $\begin{array}{l}\mathrm{CO} \\
\mathrm{SC}\end{array}$ & $\begin{array}{l}\text { Tert } \\
\text { iary }\end{array}$ \\
\hline \multirow{4}{*}{$\begin{array}{l}\text { Conc } \\
\text { erns } \\
\text { about } \\
\text { chan } \\
\text { ging } \\
\text { weat } \\
\text { her } \\
\text { patte } \\
\text { rns? }\end{array}$} & $\begin{array}{l}\text { Not at } \\
\text { all } \\
\text { conce } \\
\text { rned }\end{array}$ & $\%$ & 3.9 & 2.4 & $\begin{array}{c}12 . \\
5\end{array}$ & 8.9 & 0.0 & 0.0 & 0.0 & 5.0 \\
\hline & $\begin{array}{c}\text { A } \\
\text { little } \\
\text { conce } \\
\text { rned }\end{array}$ & $\%$ & $\begin{array}{c}10 . \\
5\end{array}$ & 5.5 & 6.2 & 11.1 & $\begin{array}{c}20 . \\
0\end{array}$ & 9.1 & 100 & 6.7 \\
\hline & $\begin{array}{l}\text { Conc } \\
\text { erned }\end{array}$ & $\%$ & $\begin{array}{c}19 . \\
7\end{array}$ & $\begin{array}{c}25 . \\
2\end{array}$ & $\begin{array}{c}25 . \\
0\end{array}$ & 31.1 & $\begin{array}{r}40 . \\
0\end{array}$ & $\begin{array}{c}27 . \\
3\end{array}$ & 0.0 & 38.7 \\
\hline & $\begin{array}{c}\text { Very } \\
\text { conce } \\
\text { rned }\end{array}$ & $\%$ & $\begin{array}{c}65 . \\
8\end{array}$ & $\begin{array}{c}66 . \\
9\end{array}$ & $\begin{array}{c}56 . \\
2\end{array}$ & 48.9 & $\begin{array}{c}40 . \\
0\end{array}$ & $\begin{array}{c}63 . \\
6\end{array}$ & 0.0 & 49.6 \\
\hline
\end{tabular}

Source: Author-generated field data

According to Figure 16 below, $63 \%$ of the respondents said it was the responsibility of the government to promote the use of SWHs by highlighting its environmental benefits and by being exemplary in its uptake. It further showed that $17 \%$ of participants said it should be an initiative of the SWH distributors to market their product, explain how it works and its added benefits; $20 \%$ of respondents viewed it as a responsibility of the public to teach and encourage each other on the use of SWHs based on their past experiences and their knowledge of the product. Only $1 \%$ of respondents felt that other stakeholders such as Non-Governmental Organisations should promote SWHs.

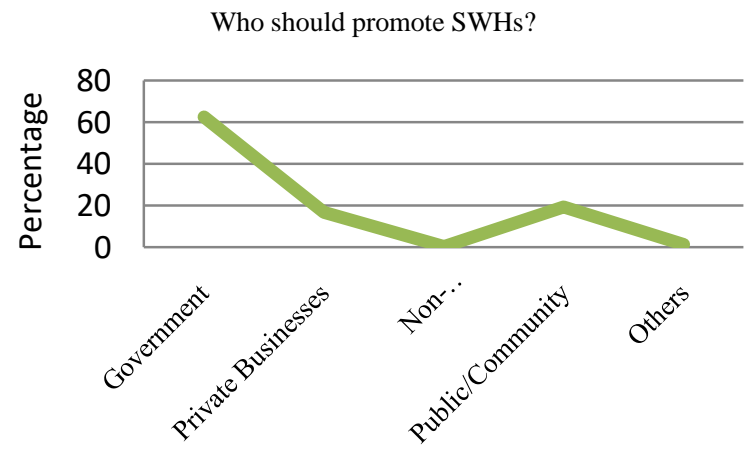

Figure 16 Who should promote SWHs? Source: Author-generated field data
Table 9 reflected that a lot of people who worked in the formal sector, $75.3 \%$, stated that the government is the one which should promote the use of SWHs. This could be that perhaps they know of effective strategies the government could use to raise awareness on solar energy. The rest of the respondents who had the same view were from the informal sector, those who were not employed and those who were self-employed. A few participants from all sectors of employment thought it was the responsibility of the public to spread the word on the use and benefits of SWHs.

There was therefore a significant association between type of employment and who respondents thought should promote SWHs, p-value $=0.005($ Chi-square $=28.335, \mathrm{df}=12)$. This could imply that a lot of people have seen initiatives taken by the government to promote the use of certain products in the country and they still think it could have an impact in doing the same for SWHs.

\begin{tabular}{|c|c|c|c|c|c|c|c|}
\hline \multicolumn{7}{|c|}{ Table 9 Type of employment in relation to opinions on who should promote } \\
\hline \multirow{1}{*}{ SWHs }
\end{tabular}

Source: Author-generated field data

Table 10 below showed various items, which measured attitude about SWHs. Agree and strongly agree responses on each item were combined into agree. Overall, the majority, more than $90 \%$, of the respondents agreed on each of the items. However, only a few, $20.8 \%$ of the low income and $16.9 \%$ of the high income agreed that thegovernment will develop other energy technologies to meet challenges of global warming. This meant the majority of respondents had a positive attitude towards being part of the global fight against global warming.

Table 2 Attitudes measured on a Likert Scale by income levels

\begin{tabular}{|c|c|c|c|c|c|c|}
\hline \multirow{2}{*}{} & \multicolumn{4}{|c|}{ Income Level of respondent } \\
\cline { 2 - 7 } & \multicolumn{2}{|c|}{$\begin{array}{c}\text { Low } \\
\text { Income }\end{array}$} & \multicolumn{2}{c|}{$\begin{array}{c}\text { High } \\
\text { Income }\end{array}$} & \multicolumn{2}{c|}{ Total } \\
\cline { 2 - 7 } & $\begin{array}{c}\text { Cou } \\
\text { nt }\end{array}$ & $\%$ & $\begin{array}{c}\text { Co } \\
\text { unt }\end{array}$ & $\begin{array}{c}\text { Co } \\
\text { un } \\
\text { t }\end{array}$ & $\%$ \\
\hline ATTITUDE & & & & & & \\
\hline $\begin{array}{c}\text { Energy education should } \\
\text { be included in the } \\
\text { curriculum. Agree } \\
\text { Disagree }\end{array}$ & 262 & 99 & 131 & 96 & 39 & 98.3 \\
\hline
\end{tabular}




\begin{tabular}{|c|c|c|c|c|c|c|}
\hline $\begin{array}{c}\text { Ways of using solar energy } \\
\text { should be a priority. } \\
\text { Agree Disagree }\end{array}$ & 258 & 97 & 127 & 93 & 38 & 96.3 \\
.7 & & & & & & \\
\hline $\begin{array}{c}\text { Government will develop } \\
\text { other energy technologies } \\
\text { to meet challenges of } \\
\text { global warming. Agree } \\
\text { Disagree }\end{array}$ & 55 & $\begin{array}{c}20 \\
.8\end{array}$ & 23 & $\begin{array}{c}16 \\
.9\end{array}$ & 78 & 19.5 \\
\hline $\begin{array}{c}\text { Given a chance, I can buy } \\
\text { SWHs provided they are } \\
\text { cheap. Agree Disagree }\end{array}$ & 248 & 93 & 123 & 90 & 37 & 92.8 \\
\hline
\end{tabular}

Source: Author-generated field data

\subsubsection{Highlights of findings for Objective 1: To establish perceptions and attitudes towards SWHs}

The following were the key findings on perceptions and attitudes of Gaborone residents towards SWHs;

a) Awareness

i. There was high awareness of solar energy between both income groups, but the proportion was significantly higher in the high-income group.

ii. Awareness was also influenced positively by education, a close correlate of income.

iii. There was a significant awareness of drought as an environmental term among respondents, other environmental terms such as renewable energy and climate change were only known by a minority.

b) Knowledge and Perception

i. There was a high perception of solar energy as a clean energy source

ii. There was a high percentage of awareness of solar energy for water heating, but significantly so among the high-income group.

iii. The majority of both income groups stated that there was limited information on SWHs.

iv. Perception of coal as a harmful source of energy was influenced by income level.

c) Attitude

i. The majority of respondents had a positive attitude towards the use of SWHs, provided they were reliable, cost effective, convenient and durable.

ii. A minority used solar energy to heat water.

iii. Positive attitude towards the use of SWHs was not linked to environmental concern.

iv. The majority asserted that it was the responsibility of the government to promote SWHs.

\subsection{Official Attitudes towards SWHs}

This section presents findings on officials' attitude towards the use of domestic solar energy, particularly SWHs. The following are what was found out during the interviews:

\subsubsection{Official justification of the promotion of SWHs}

The government officials interviewed advanced the following reasons for promoting the adoption of SWHs:

i. Widespread adoption of solar energy in general and SWHs in particular would contribute to a reduction in carbon dioxide emissions. It would do this by reducing the amount of coal being burnt to generate electricity.

ii. The use of solar water heaters had the potential to reduce water-heating costs by $60 \%$ and electricity costs by between $30 \%$ and $40 \%$ depending on the size of the household and how often they needed to use it.

iii. Solar Water Heaters increased the value of the house in the sense that during the property valuation SWHs were considered value addition assets. This was adopted internationally to try to make it easy for the renewable energy systems to penetrate the market.

iv. If adopted by Gaborone residents, SWHs could reduce peak electricity load by approximately 30 $50 \%$ and therefore the removal or reduction of electric geysers would make a noticeable difference in load shedding.

v. Depending on the size of a household, the use of SWHs could have long-term returns, as it would help reduce the amount households spent on electricity bills.

\subsubsection{Official initiatives towards promoting the use of domestic solar energy, particularly SWHs}

Presented below are the key submissions of Government officials interviewed on the issue of initiatives taken by Government to promote the adoption of domestic SWHs directly and indirectly.

i) The main role of Government was to develop policies and strategies promoting the use of solar energy. Strategies included promotions, campaigns, incentives and anything that would benefit both Batswana and investors in the adoption and marketing of SWHs. This probably explained why the majority $(63 \%)$ of respondents in Figure 16 above stated that government officials were responsible for the promotion of SWHs.

ii) Solar energy was taught in schools through Environmental Clubs and the Department of Environmental Affairs (DEA) provided teaching materials whenever they were invited for presentations. The Department of Energy Affairs was also trying its best to spread word to the public by buying SWHs from distributors through government procurement procedures and making demonstrations in exhibition shows and consumer fairs. There was reportedly a positive response from the public especially that the current models were well insulated and could keep water heated for longer periods. In 
these exhibitions, the Department of Energy Affairs only raised awareness and referred interested individuals to the distributors, but they never kept records, made follow-ups nor obtained necessary feedback to gauge the impact of the exhibitions. In addition, Table 12 indicated that $98.3 \%$ of the respondents agreed that energy education should be included in school curricula.

iii) The Department of Energy Affairs (now Department of Energy) in conjunction with the World Bank was developing Renewable Energy Strategies and Renewable Energy Efficiency and Conservation Strategies to create a conducive environment for the adoption of clean energy technologies, including SWHs. These strategies were anticipated to be in place at least by 2017, and these will include incentives on renewable energy use.

iv) It was reportedly a government goal that every government institution uses SWHs to save on electricity costs. At the time of the study most of the SWHs in government institutions were reported not to be in good working conditions due to lack of maintenance. There were reportedly insufficient funds for maintenance.

v) There was an ongoing project of assessing SWHs in government institutions. The officials were trying to establish how many SWHs needed maintenance and replacement, how many were not working, what faults were there and cost implications. However, this project was reportedly challenged due to lack of funds but different stakeholders were being taken on board for financial support and action was awaited from their end.

vi) The Department of Energy Affairs was also considering liaising with the Botswana Unified Revenue Service (BURS) to restrict the types of SWHs imported from other countries for quality assurance. Low quality ones will not be allowed in Botswana since their lifespan was short and replacing them often meant incurring more costs. This, however, was still at a conceptual stage.

vii) SWHs were not affordable for low income earners; they were very expensive for this category of potential consumers. This was further supported by Table 8, which indicated that generally people who earned low incomes preferred affordable sources of energy such as gas and paraffin. Concerning this, the Department of Energy Affairs could once in a while do donations of SWHs to the disadvantaged in the cases where they were the ones who had built them houses. The Department had not yet done this for many households since this was a new initiative.

viii) There was no government programme yet to assist low income households to buy and install SWHs, but there was reportedly a running tender for the Renewable Energy Agency to assist in that. The company awarded this tender will see how best they could promote the installation of SWHs and the Renewable Energy Fund released by the Department of Energy Affairs will be utilized by the Agency to promote renewable energy among households of all income levels.

\subsubsection{Officials' Adoption of SWHs}

Government officials' uptake of SWHs was not yet satisfactory because the stock of government institutional houses was not enough for all civil servants. Most officials therefore live in rented houses in Gaborone and they did not have a choice on the type of heating system to use.

\subsubsection{Major Government SWH Adopters}

These were identified as police office houses in Old Naledi. These houses have had solar water heaters from the beginning, their occupants were aware that they use solar and not electric geysers. The major benefit of these systems to them was their ability to save them electricity costs. They were not fully informed of their environmental benefits. These devices were said to be effective especially during summer, in winter the water heating process slowed down to an extent that they were forced to use electric powered element buckets to meet the solar panels half way. For larger families, it was a challenge, especially if they were forced to take a bath at the same time as warm water finished and they had to wait for it to be heated again. There were some residents who complained about lack of maintenance, they had reported faults in their systems but their maintenance departments took time to respond.

The researcher had a chance to interview the relevant maintenance officer who explained that he was not oriented on how these devices operate, so even when they were faulty he could only fix to a certain extent using the little knowledge he acquired from his friends and this was usually not sustainable and he sometimes failed to rectify the problem identified. He also added that, these companies just came for the installation and they never went for monitoring and he did not have the power to contact them directly for assistance because there would be other issues of procurement logistics, especially where maintenance and replacement were required.

\subsubsection{Perspectives of vendors of SWHs}

Vendors of SWHs in Gaborone identified were Sola Hart, Solar International, Solar One, Solar Power and Mega Sun. Two distributors, Solar Power and Sola Hart were interviewed and the following were their perspectives on SWHs and the initiatives they claimed they took to promote their adoption, as well as their views on SWH affordability and official and public attitudes towards SWHs.

\subsubsection{Background Information on SWHs}

i) SWHs were not harmful to the environment because they did not produce any threatening emissions. 
ii) One of the major benefits of using SWHs was that they could save the consumer some money because electric geysers use a lot of electricity.

iii) SWHs could be used for convenience as a back up during load shedding hours.

iv) The electric geyser could be converted into a solar heated water tank. The solar panel could be placed at the rooftop then plumbing done from the panel to the tank. There will be no change or interference with the existing wiring. In this way the geyser could use both solar and electricity for the owner's convenience. One would need pipes, solar connector panel (it heats water) and a controller (monitors the water temperature). The connector panel receives energy and passes it onto the water, hot water is then stored in the tank.

v) SWHs were claimed to be more reliable than electric geysers because during manufacturing it was considered that they would be exposed to the sun and therefore the materials used were able to withstand those weather conditions. This was not the case with electric geysers as they would be in the shade the whole or most of the time. Materials used to make SWHs were copper and stainless steel, they were the same materials used for electric geysers except that they were made thicker for SWHs and hence their durability. SWHs' warranty period was 5 years while electric geysers were given a 2-year warranty.

vi) The maintenance of SWHs and electric geysers was the same except that for SWHs the solar panel glass needed to be regularly cleaned (either wiped with a cloth if it is within one's reach or be splashed with water using a hosepipe if one cannot reach for it). The main idea was to avoid dust from accumulating on it, during rainy days there was no need to clean it up since the rain does it. The panel should also be checked to ensure that it is not shaded away from the sun since the sun is its source of energy. The lifespan of the tank was 10 to 12 years.

vii) Their major customers were private contractors who were doing government projects; this meant the government was their indirect customer.

\subsubsection{Vendors' initiatives towards promoting SWHs}

i) Vendors tried their best to be there at annual consumer fairs to market SWHs. In marketing their products, they explained their benefits in terms of money savings and how they were used.

ii) They also claimed to hold radio interviews at least once a month where the public were free to interrogate them. Their observation was that Batswana were more concerned about the high cost of SWHs rather than about their potential environmental benefits. The vendors felt that they were not yet doing enough to support SWHs because if it was enough then its uptake would be noticeable. iii) Vendors also claimed to have partnered with stakeholders such as BPC to promote SWHs; for example, together they sponsored campaigns where solar energy education was taught and held competitions. The winners got free SWHs installed for them and received full orientation of how to use and care for them. This was a new campaign; they claimed to have had only one winner so far.

iv) They reported to have taken an initiative of partnering with banks so that the cost of SWHs could be incorporated in the mortgages and then they (the vendors) could get their share as per their agreement with the selected banks.

\subsubsection{Vendors' views on affordability}

i) The vendors claimed that the affordability of SWHs depended on the individual's need to buy and use them since they had arrangements of paying in installments. The systems cost around P13 000 excluding installation fee and P20 000 including installation fee. For one to buy the system on installment terms an agreement was reached on how much one could afford monthly then one would pay while the system is still with distributors. Once the payment was complete then the vendor would do the installation.

ii) The vendors could not cut the cost of SWHs because the majority of the costs were on the materials being used, cutting costs would mean cutting on the materials being used and therefore jeopardizing the quality of the systems, which would in turn mean reduced durability.

iii) As at the time of the study, low income residents could not engage in that arrangement. There was no government scheme as yet to assist them buy SWHs.

\subsubsection{Vendors' perspectives on official attitude}

i. The Government of Botswana did not seem to appreciate the use of SWHs. In government institutions, especially schools, they did install SWHs which were reportedly not regularly inspected and maintained. When these got dysfunctional due to lack of maintenance, they were reportedly replaced with electric geysers.

ii. The government had long been approached about subsidizing SWHs, especially by the local manufacturers of SWHs, but government was reportedly focused on having Morupule B power station fixed rather than promoting the use of alternative and cleaner energy sources such as solar power.

\subsubsection{Vendors' perspectives on Public Attitude}

i. The public did recognize the benefits of domestic solar energy during exhibitions, but they always brought up the issue of devices not being effective during winter. They did not consider the fact that 
even during conventional power cuts they would go without electricity.

ii. The public showed interest and some knowledge during exhibitions but their main hindrance was the high costs of SWHs; they then preferred to install the 'cheaper' electric geysers whenever they built their own houses. This was further indicated by Figure 14 (Would you use SWHs?), which showed that $86 \%$ of the respondents had a positive attitude towards the use of SWHs.

iii. Batswana were concerned that, if solar power was an alternative to coal-based electricity, then why was the government not taking action towards promoting its usage. They were scared to take the risk of adopting domestic solar energy when the government was not so loud about it.

\subsubsection{Highlights of findings for Objective 2: To find out official attitudes towards SHWs.}

The key findings on official attitudes towards SWHs are listed below:

i. Government officials had a positive attitude towards the use of SWHs, according to them the adoption was important for greenhouse gas emissions reasons; it reduced energy costs and load shedding, and it also added value to property.

ii. Generally, there were positive official initiatives towards the promotion of solar energy, but these initiatives were not easy to promote among the low income households because of affordability constraints.

iii. Government officials' uptake of the use of SWHs was not yet satisfactory as adoption was only limited to institutional houses, which were few.

iv. Vendors presented many positive aspects about SWHs, and they had advanced several initiatives to market SWHs but they reported limited government commitment.

\subsection{Determinants of Household Attitudes towards SWHs}

In this section, an attempt was made to use Chi-square Analysis and the Multivariate Logistic model to establish the factors with actual or likely influence on household/public attitudes towards SWHs in Gaborone.

Table 11 below indicated the possible influence of gender, education, employment status, monthly earnings and residential income level on willingness to adopt SWHs. The majority of males $(92.8 \%)$ would consider using SWHs and only $7.2 \%$ would not use it. The difference between females and males who could adopt the use of SWHs was statistically significant with a p-value $<0.001$ (Chi-square $=10.524, \mathrm{df}=$ 1).

The more educated the respondent was the more likely they would adopt to the use of SWHs. There was a significant association between adoption and education status, p-value 0.009, (chi-square $=11.639, \mathrm{df}=3$ ).

The type of employment did not have much influence on the adoption of SWHs, p-value 0.248, (Chi-square $=4.127, \mathrm{df}=3$ ).

Among the respondents who earned more than P10 000, 93.1\% would adopt SWHs and only $6.9 \%$ stated they would not consider adopting SWHs. The percentages did not differ much between those who would adopt SWHs and had no salary or were earning less than P2000. There was therefore an association between adoption and monthly income, $\mathrm{p}$-value 0.100, (Chi-square $=7.166$, df $=4$ ). Surprisingly, however, staying in low income or high income residential area seemed to have an influence on willingness to adopt SWHs ( $\mathrm{p}=$ $<0.05$, Chi-square $=4.273$, df $=1)$. Generally, these Chisquare results suggested that willingness to adopt SWHs was influenced by gender, education level and residential income level, but not associated with monthly earnings and type of employment.

\begin{tabular}{|c|c|c|c|c|c|c|c|c|}
\hline \multicolumn{7}{|c|}{$\begin{array}{l}\text { Table } 11 \text { The influence of demographic characteristics on } \\
\text { attitudes towards the adoption/use of SWHs }\end{array}$} & & \\
\hline & & \multicolumn{5}{|c|}{ Would you consider using it? } & \multirow{3}{*}{$\begin{array}{c}\mathrm{p}- \\
\text { value }\end{array}$} & \multirow{3}{*}{$\begin{array}{c}\text { Chi- } \\
\text { square } \\
\text { (df) }\end{array}$} \\
\hline & & \multicolumn{2}{|c|}{ Yes } & \multicolumn{2}{|c|}{ No } & \multirow{2}{*}{$\begin{array}{c}\begin{array}{c}\text { Tot } \\
\text { al }\end{array} \\
\mathrm{N}\end{array}$} & & \\
\hline & & $\mathrm{N}$ & $\%$ & $\mathrm{~N}$ & $\%$ & & & \\
\hline \multirow{2}{*}{$\begin{array}{c}\text { Gender of } \\
\text { responden } \\
t\end{array}$} & Male & $\begin{array}{c}15 \\
5\end{array}$ & $\begin{array}{c}92 . \\
8\end{array}$ & $\begin{array}{l}1 \\
2\end{array}$ & 7.2 & 167 & $\begin{array}{l}<0.0 \\
01\end{array}$ & $\begin{array}{c}10.524( \\
1)\end{array}$ \\
\hline & Female & $\begin{array}{c}18 \\
9\end{array}$ & $\begin{array}{c}81 . \\
5\end{array}$ & $\begin{array}{l}4 \\
3\end{array}$ & $\begin{array}{c}18 . \\
5\end{array}$ & 232 & & \\
\hline \multirow{4}{*}{$\begin{array}{l}\text { Education } \\
\text { Status }\end{array}$} & PSLE & 62 & $\begin{array}{c}77 . \\
5\end{array}$ & $\begin{array}{l}1 \\
8\end{array}$ & $\begin{array}{c}22 . \\
5\end{array}$ & 80 & 0.009 & $\begin{array}{c}11.639( \\
3)\end{array}$ \\
\hline & BGSE & $\begin{array}{c}11 \\
6\end{array}$ & $\begin{array}{c}84 . \\
1\end{array}$ & $\begin{array}{l}2 \\
2\end{array}$ & $\begin{array}{c}15 . \\
9\end{array}$ & 138 & & \\
\hline & COSC & 14 & $\begin{array}{c}82 . \\
4\end{array}$ & 3 & $\begin{array}{c}17 . \\
6\end{array}$ & 17 & & \\
\hline & Tertiary & $\begin{array}{c}15 \\
2\end{array}$ & $\begin{array}{c}92 . \\
7\end{array}$ & $\begin{array}{l}1 \\
2\end{array}$ & 7.3 & 164 & & \\
\hline \multirow{4}{*}{$\begin{array}{l}\text { Type of } \\
\text { employm } \\
\text { ent }\end{array}$} & Formal & $\begin{array}{c}13 \\
2\end{array}$ & $\begin{array}{c}90 . \\
4\end{array}$ & $\begin{array}{l}1 \\
4\end{array}$ & 9.6 & 146 & 0.248 & $\begin{array}{c}4.127 \\
(3)\end{array}$ \\
\hline & Informal & 74 & $\begin{array}{c}86 . \\
0\end{array}$ & $\begin{array}{l}1 \\
2\end{array}$ & $\begin{array}{c}14 . \\
0\end{array}$ & 86 & & \\
\hline & $\begin{array}{c}\text { Unemploy } \\
\text { ed }\end{array}$ & 67 & $\begin{array}{c}83 . \\
8\end{array}$ & $\begin{array}{l}1 \\
3\end{array}$ & $\begin{array}{c}16 . \\
2\end{array}$ & 80 & & \\
\hline & $\begin{array}{c}\text { Self } \\
\text { Employed }\end{array}$ & 71 & $\begin{array}{c}81 . \\
6\end{array}$ & $\begin{array}{l}1 \\
6\end{array}$ & $\begin{array}{c}18 . \\
4\end{array}$ & 87 & & \\
\hline \multirow{5}{*}{$\begin{array}{l}\text { monthly } \\
\text { Income }\end{array}$} & $<2000$ & $\begin{array}{c}11 \\
8\end{array}$ & $\begin{array}{c}88 . \\
1\end{array}$ & $\begin{array}{l}1 \\
6\end{array}$ & $\begin{array}{c}11 . \\
9\end{array}$ & 134 & 0.127 & $\begin{array}{c}7.166(4 \\
)\end{array}$ \\
\hline & $\begin{array}{c}3000- \\
5000\end{array}$ & 38 & $\begin{array}{c}88 . \\
4\end{array}$ & 5 & $\begin{array}{c}11 . \\
6\end{array}$ & 43 & & \\
\hline & $\begin{array}{l}5000- \\
10000 \\
\end{array}$ & 35 & $\begin{array}{c}87 . \\
5 \\
\end{array}$ & 5 & $\begin{array}{c}12 . \\
5\end{array}$ & 40 & & \\
\hline & $>10000$ & 54 & $\begin{array}{c}93 . \\
1\end{array}$ & 4 & 6.9 & 58 & & \\
\hline & No salary & 99 & $\begin{array}{c}79 . \\
8\end{array}$ & $\begin{array}{l}2 \\
5\end{array}$ & $\begin{array}{c}20 . \\
2\end{array}$ & 124 & & \\
\hline \multirow{3}{*}{$\begin{array}{l}\text { Income } \\
\text { Level of } \\
\text { responden } \\
t\end{array}$} & $\begin{array}{l}\text { Low } \\
\text { Income }\end{array}$ & $\begin{array}{c}22 \\
0\end{array}$ & $\begin{array}{c}83 . \\
7\end{array}$ & $\begin{array}{l}4 \\
3\end{array}$ & $\begin{array}{c}16 . \\
3\end{array}$ & 263 & 0.039 & $\begin{array}{c}4.273(1 \\
)\end{array}$ \\
\hline & $\begin{array}{c}\text { High } \\
\text { Income }\end{array}$ & $\begin{array}{c}12 \\
4\end{array}$ & $\begin{array}{c}91 . \\
2\end{array}$ & $\begin{array}{l}1 \\
2\end{array}$ & 8.8 & 136 & & \\
\hline & Total & $\begin{array}{c}34 \\
4\end{array}$ & $\begin{array}{c}86 . \\
2\end{array}$ & $\begin{array}{l}5 \\
5\end{array}$ & $\begin{array}{c}13 . \\
8\end{array}$ & 399 & & \\
\hline
\end{tabular}

Source: Author-generated field data 


\section{Multivariate Logistic Analysis}

To evaluate the joint effect of potential predictors of awareness, a multivariate logistic model was used. The logistic model was appropriate for binary response variables e.g. awareness. In addition, the model allowed for assessment of each predictor variable controlling for other variables, i.e. in the presence of other variables whereas the chi-square tests were assessing the association between the response and individual potential predictors separately.

$$
\begin{aligned}
\operatorname{logit}(P)=\beta_{0} & +\beta_{1} \text { Male }+\beta_{2} \text { P.S.L.E }+\beta_{3} \text { B.G.C.S.E } \\
& +\beta_{4} \text { COSC }+\beta_{5} \text { Informal }+\beta_{6} \text { Fomal } \\
& +\beta_{7} \text { Unemployed }+\beta_{8} \text { Lowincome } \\
& +\beta_{9} \text { Middleincome } \\
& +\beta_{10} \text { Middlehighincome } \\
& +\beta_{11} \text { Highincome } \\
& +\beta_{12} \text { LowincomeResidentialArea }
\end{aligned}
$$

From this model, the $\beta$ coefficients in the model indicated the effect of the corresponding variable on the response. The significance of each predictor variable was indicated by its $\mathrm{p}$ value. P-value less than or equal to $5 \%$ was considered significant. SPSS further provided the log likelihood ratio chi square test to evaluate the goodness of fit of the model.

The following Table 12 presents results of a logistic model to assess the joint effect of socio-demographic factors on the awareness/perception of SWHs signified by the question, "Do you know anything about solar energy". The table illustrates that gender correlated significantly with awareness, p-value 0.010. Education was significant in determining awareness, $\mathrm{p}$ value $=0.014$. Employment status was not significant in determining awareness, $\mathrm{p}$-value $=0.31$. Income was not a determinant of awareness, $\mathrm{p}$-value $=0.356$ and neither was income level of residential area at a p-value of 0.511 .

Other significant predictor variables were education and

\begin{tabular}{|c|c|c|c|c|c|c|c|}
\hline & & B & S.E. & $\begin{array}{c}\text { Wal } \\
\mathrm{d}\end{array}$ & $\mathrm{df}$ & $\begin{array}{c}\text { p- } \\
\text { valu } \\
\mathrm{e}\end{array}$ & $\begin{array}{l}\operatorname{Exp}( \\
\text { B) }\end{array}$ \\
\hline \multirow{7}{*}{$\begin{array}{l}\text { Step } \\
1^{\mathrm{a}}\end{array}$} & Gender(Male) & -.882 & 0.341 & $\begin{array}{c}6.69 \\
7\end{array}$ & 1 & $\begin{array}{c}0.01 \\
0\end{array}$ & 0.414 \\
\hline & Education & & & $\begin{array}{c}10.5 \\
55\end{array}$ & 3 & $\frac{0.01}{4}$ & \\
\hline & $\begin{array}{l}\text { Education(P.S. } \\
\text { L.E) }\end{array}$ & 2.098 & 0.653 & $\begin{array}{c}10.3 \\
04\end{array}$ & 1 & $\begin{array}{c}0.00 \\
1\end{array}$ & 8.146 \\
\hline & $\begin{array}{c}\text { Education(B.G. } \\
\text { C.S.E) }\end{array}$ & 1.810 & 0.622 & $\begin{array}{c}8.47 \\
3\end{array}$ & 1 & $\begin{array}{c}0.00 \\
4\end{array}$ & 6.113 \\
\hline & $\begin{array}{c}\text { Education(COS } \\
\text { C) }\end{array}$ & 1.554 & 0.880 & $\begin{array}{c}3.11 \\
6\end{array}$ & 1 & $\begin{array}{c}0.07 \\
8\end{array}$ & 4.728 \\
\hline & Employment & & & $\begin{array}{c}8.90 \\
9\end{array}$ & 3 & $\frac{0.03}{1}$ & \\
\hline & $\begin{array}{l}\text { Employment(In } \\
\text { formal) }\end{array}$ & $\begin{array}{c}- \\
1.060\end{array}$ & 0.611 & $\begin{array}{c}3.00 \\
8\end{array}$ & 1 & $\begin{array}{c}0.08 \\
3\end{array}$ & 0.346 \\
\hline
\end{tabular}
employment type; residential area and monthly income were

\begin{tabular}{|c|c|c|c|c|c|c|}
\hline $\begin{array}{l}\text { Employment(Fo } \\
\text { rmal) }\end{array}$ & 0.125 & 0.474 & .069 & 1 & $\begin{array}{c}0.79 \\
3\end{array}$ & 1.133 \\
\hline $\begin{array}{c}\text { Employment(U } \\
\text { nemployed) }\end{array}$ & $\begin{array}{c}- \\
1.026 \\
\end{array}$ & 0.461 & $\begin{array}{c}4.96 \\
2\end{array}$ & 1 & $\begin{array}{c}0.02 \\
6\end{array}$ & 0.358 \\
\hline Income & & & $\begin{array}{c}4.38 \\
5\end{array}$ & 4 & $\frac{0.35}{6}$ & \\
\hline $\begin{array}{c}\text { Low } \\
\text { Income }(<2000)\end{array}$ & -.858 & 0.476 & $\begin{array}{c}3.24 \\
2\end{array}$ & 1 & $\begin{array}{c}0.07 \\
2\end{array}$ & 0.424 \\
\hline $\begin{array}{c}\text { Medium } \\
\text { Income }(3000- \\
5000)\end{array}$ & -.278 & 0.670 & $\begin{array}{c}0.17 \\
3\end{array}$ & 1 & $\begin{array}{c}0.67 \\
8\end{array}$ & 0.757 \\
\hline $\begin{array}{l}\text { Medium High } \\
\text { Income }(5000- \\
10000)\end{array}$ & 0.251 & 0.940 & $\begin{array}{c}0.07 \\
2\end{array}$ & 1 & $\begin{array}{c}0.78 \\
9\end{array}$ & 1.286 \\
\hline $\begin{array}{c}\text { High Income } \\
(>10000)\end{array}$ & -.606 & 0.967 & $\begin{array}{c}0.39 \\
3\end{array}$ & 1 & $\begin{array}{c}0.53 \\
1\end{array}$ & 0.545 \\
\hline $\begin{array}{l}\text { Residential area } \\
\text { (Low Income } \\
\text { residence) }\end{array}$ & -.385 & 0.586 & $\begin{array}{c}0.43 \\
2\end{array}$ & 1 & $\frac{0.51}{\underline{1}}$ & 0.680 \\
\hline Constant & $\begin{array}{c}- \\
1.808\end{array}$ & 0.605 & $\begin{array}{c}8.94 \\
2\end{array}$ & 1 & $\begin{array}{c}0.00 \\
3\end{array}$ & 0.164 \\
\hline
\end{tabular}
not significant in the model. There was no difference in the awareness of solar energy between the residential areas. The goodness fit of the model was supported by the log likelihood, chi-square $=277.933, \mathrm{p}$-value $<0.001$ and model chi-square $=$ 45.736, df $=12$, p-value $<0.001$.
Income Level.

Source: Author-generated field data

Similarly, a logistic model was used to assess the contributory effect of socio-demographic factors on adoption of SWHs signified by the question, "Would you consider using solar energy". Table 13 below illustrates that gender was associated with adoption, p-value 0.001. Employment status did not have

\begin{tabular}{|c|c|c|c|c|c|c|c|}
\hline \multicolumn{8}{|c|}{ Table 4 Would you consider using solar energy? (Logistic Model) } \\
\hline & & B & S.E. & Wald & $\begin{array}{l}\mathrm{d} \\
\mathrm{f}\end{array}$ & Sig. & $\begin{array}{c}\operatorname{Exp}( \\
\text { B) }\end{array}$ \\
\hline \multirow{11}{*}{$\begin{array}{l}\text { Ste } \\
\mathrm{p} \\
1^{\mathrm{a}}\end{array}$} & Gender(Male) & $\begin{array}{c}- \\
1.13 \\
1\end{array}$ & $\begin{array}{c}0.35 \\
6\end{array}$ & $\begin{array}{c}10.09 \\
1\end{array}$ & 1 & $\begin{array}{c}0.00 \\
1\end{array}$ & 0.323 \\
\hline & Education & & & 6.579 & 3 & $\begin{array}{c}0.08 \\
7\end{array}$ & \\
\hline & Education(P.S.L.E) & $\begin{array}{c}1.45 \\
2\end{array}$ & $\begin{array}{c}0.57 \\
2\end{array}$ & 6.444 & 1 & $\begin{array}{c}0.01 \\
1\end{array}$ & 4.271 \\
\hline & Education(B.G.C.S.E) & $\begin{array}{c}0.95 \\
2\end{array}$ & $\begin{array}{c}0.53 \\
9\end{array}$ & 3.120 & 1 & $\begin{array}{c}0.07 \\
7\end{array}$ & 2.591 \\
\hline & Education(COSC) & $\begin{array}{c}0.90 \\
7\end{array}$ & $\begin{array}{c}0.81 \\
9\end{array}$ & 1.225 & 1 & $\begin{array}{c}0.26 \\
8\end{array}$ & 2.477 \\
\hline & Employment & & & 1.079 & 3 & $\begin{array}{c}0.78 \\
2\end{array}$ & \\
\hline & $\begin{array}{c}\text { Employment(Informal } \\
\text { ) }\end{array}$ & $\begin{array}{c}- \\
0.36 \\
9\end{array}$ & $\begin{array}{c}0.56 \\
7\end{array}$ & 0.424 & 1 & $\begin{array}{c}0.51 \\
5\end{array}$ & 0.691 \\
\hline & Employment(Formal) & $\begin{array}{c}- \\
0.14 \\
8\end{array}$ & $\begin{array}{c}0.51 \\
6\end{array}$ & 0.082 & 1 & $\begin{array}{c}0.77 \\
4\end{array}$ & 0.862 \\
\hline & $\begin{array}{l}\text { Employment(Unemplo } \\
\text { yed) }\end{array}$ & $\begin{array}{c}- \\
0.41 \\
5\end{array}$ & $\begin{array}{c}0.44 \\
3\end{array}$ & 0.876 & 1 & $\begin{array}{c}0.34 \\
9\end{array}$ & 0.660 \\
\hline & Income & & & 4.041 & 4 & $\begin{array}{c}0.40 \\
1\end{array}$ & \\
\hline & Income $(>2000)$ & $\begin{array}{c}- \\
0.74\end{array}$ & $\begin{array}{c}0.48 \\
7\end{array}$ & 2.337 & 1 & $\begin{array}{c}0.12 \\
6\end{array}$ & 0.475 \\
\hline
\end{tabular}
an association with adoption, $\mathrm{p}$-value $=0.782$. Monthly income was not a determinant of adoption, $\mathrm{p}$-value $=0.401$ and income level at a p-value of 0.613. Education was not significant in determining adoption, $\mathrm{p}$-value $=0.087$. However, secondary and primary education portrayed significant difference compared to tertiary level. 


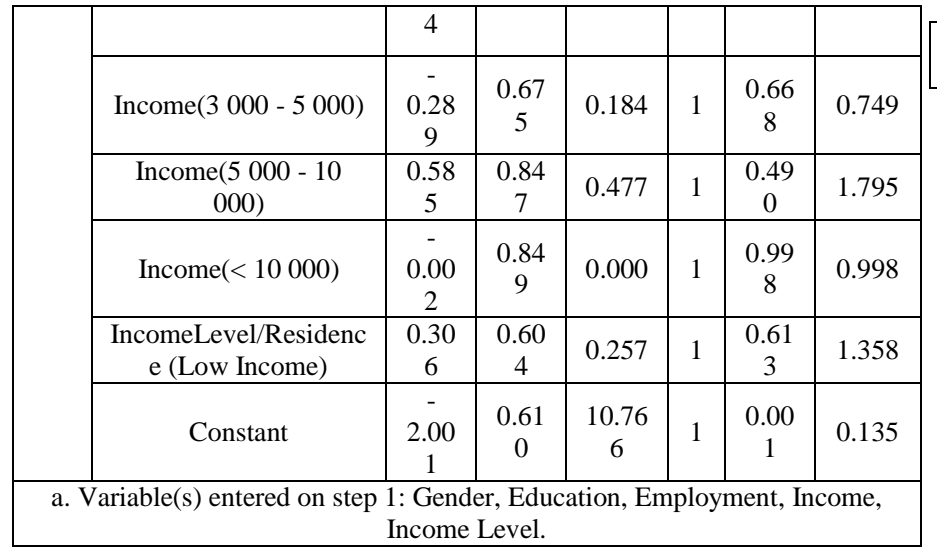

Source: Author-generated field data

Do you know anything about solar energy and would you consider using it?

Various knowledge aspects on SWHs were included in the questionnaire; their influence on attitude towards domestic solar energy was assessed separately. The knowledge questions included "Do you know anything about solar energy?", "Is information on SWHs available for the public?" These were further cross-tabulated by income levels of respondents.

Table 14 indicates that among the low-income residents, a high percentage, $96 \%$ who knew anything on solar energy would consider using it compared to the $26 \%$ who did not know anything in the same income level. This difference was significant, $\mathrm{p}$-value $<0.001$ (Chi-square $=135.1, \mathrm{df}=1)$. Among the high-income residents, a high percentage, 93.7\% who knew anything on solar energy would consider using it compared to the $60 \%$ who did not know anything in the same income level. This difference was significant, $\mathrm{p}$-value $<0.001$ (Chi-square $=13.041, \mathrm{df}=1)$. Overall association between knowledge about solar energy and considering using solar energy was significant $\mathrm{p}$ value $<0.001$, (Mantel-Haenszel Chisquare $=142.013$, df $=1)$. Normally, one would prefer to use an item they have seen effective somewhere based on the feedback derived from those with first-hand information on it , this explains why the majority of respondents who have heard about SWHs would consider using it.

\begin{tabular}{|c|c|c|c|c|c|c|c|c|}
\hline & & & & & & & & \\
\hline & & & & ow In & & & gh In & \\
\hline & & & & $\begin{array}{l}\text { d you } \\
\text { using }\end{array}$ & sider & & $\begin{array}{l}\text { you } \\
\text { using }\end{array}$ & sider \\
\hline & & & Yes & No & Total & Yes & No & Total \\
\hline \multirow{5}{*}{$\begin{array}{c}\text { know } \\
\text { anything } \\
\text { about } \\
\text { solar } \\
\text { energy }\end{array}$} & \multirow[b]{2}{*}{ Yes } & $\%$ & 95.9 & 4.1 & 100.0 & 93.7 & 6.3 & 100.0 \\
\hline & & $\begin{array}{l}\text { Co } \\
\text { unt }\end{array}$ & 208 & 9 & 217 & 118 & 8 & 126 \\
\hline & \multirow{2}{*}{ No } & $\%$ & 26.1 & 73.9 & 100.0 & 60.0 & 40.0 & 100.0 \\
\hline & & $\begin{array}{l}\text { Co } \\
\text { unt }\end{array}$ & 12 & 34 & 46 & 6 & 4 & 10 \\
\hline & Tota & $\%$ & 83.7 & 16.3 & 100.0 & 91.2 & 8.8 & 100.0 \\
\hline
\end{tabular}

\begin{tabular}{|l|l|l|l|l|l|l|l|l|}
\hline & 1 & $\begin{array}{c}\text { Co } \\
\text { unt }\end{array}$ & 220 & 43 & 263 & 124 & 12 & 136 \\
\hline
\end{tabular}

Source: Author-generated field data

In Figure 17 below, about $81 \%$ of the participants did not know of any place they could easily access information on SWHs, which meant many people lacked knowledge on SWHs. Only $19 \%$ agreed that there was information on the use and efficiency of SWHs available for the public. This, therefore, might have contributed to the low number of people who used solar as their source of energy according to Figure 13 . The majority of people $(86 \%)$ might have heard something on SWHs (Figure 9), but their uptake of them was likely hindered by lack of access to relevant information.

Is information on SWHs available for the public?

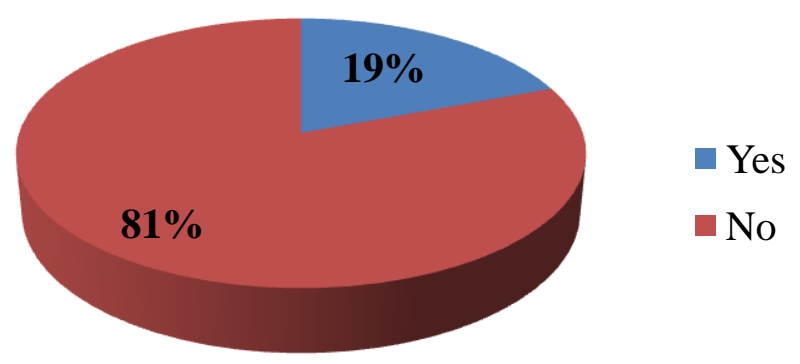

Figure 17 Public information on SWHs

Source: Author-generated field data

In Figure 18 below, $70 \%$ of the participants did not know of any distributors of SWHs in Gaborone, and the $30 \%$ who knew only mentioned Chinese shops where they bought mini solar panels used for electric appliances and lights.

Do you know of any SWHs distributors in Gaborone?

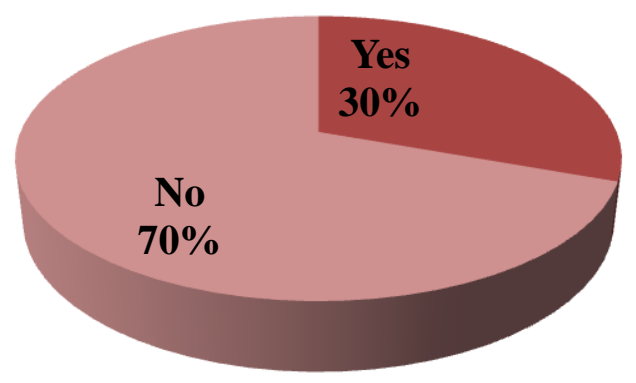

Figure 18 Vendors of SWHs in Gaborone

Source: Author-generated field data 


\subsubsection{Public information on SWHs and distributors of SWHs in Gaborone}

Table 15 indicates that among the low-income residents, $55.7 \%$ who said there was no information available for the public on SWHs did not know any distributors of SWHs in Gaborone as compared to the $11 \%$ who said information was available. This difference was statistically significant, $p$-value 0.002 (Chi-square $=9.905, \mathrm{df}=1$ ).Peoples' interest in a product is usually triggered by hearing about it often and knowing exactly where to go if they wanted to enquire more about it or indeed to purchase the product. It therefore made sense that the unavailability of information on SWHs was linked to the lack of knowledge on distributors of SWHs.

Among the high-income residents, $76.5 \%$ who said there was no information available on SWHs for the public did not know any retailers of SWHs in Gaborone as compared to the $5.9 \%$ who said information was available. This difference was significant, p-value 0.087 (Chi-square $=2.928, \mathrm{df}=1)$.

Overall, the association between availability of public information on SWHs and knowledge of SWHs vendors in Gaborone was significant p-value 0.001 (Mantel-Haenszel Chi-square $=11.803$, df $=1$ ).If there was no public information about SWHs, people were less likely to know about where they were sold. One would be interested in distributors only if they were well informed about SWHs.

\begin{tabular}{|c|c|c|c|c|c|c|}
\hline \multirow{2}{*}{\multicolumn{4}{|c|}{ Income Level of respondent }} & \multicolumn{2}{|c|}{$\begin{array}{c}\text { Know any SHWs } \\
\text { distributors in } \\
\text { Gaborone? }\end{array}$} & \multirow[t]{2}{*}{ Total } \\
\hline & & & & Yes & No & \\
\hline \multirow{6}{*}{$\begin{array}{l}\text { Low } \\
\text { Income }\end{array}$} & \multirow{4}{*}{$\begin{array}{l}\text { Is information } \\
\text { on SWHs } \\
\text { available for } \\
\text { the public? }\end{array}$} & \multirow[b]{2}{*}{ Yes } & Count & 29 & 27 & 56 \\
\hline & & & $\begin{array}{l}\% \text { of } \\
\text { Total }\end{array}$ & $11.0 \%$ & $10.2 \%$ & $\begin{array}{c}21.2 \\
\%\end{array}$ \\
\hline & & \multirow[b]{2}{*}{ No } & Count & 61 & 147 & 208 \\
\hline & & & $\begin{array}{l}\% \text { of } \\
\text { Total }\end{array}$ & $23.1 \%$ & $55.7 \%$ & $\begin{array}{c}78.8 \\
\% \\
\end{array}$ \\
\hline & \multirow{2}{*}{\multicolumn{2}{|c|}{ Total }} & Count & 90 & 174 & 264 \\
\hline & & & $\begin{array}{l}\% \text { of } \\
\text { Total }\end{array}$ & $34.1 \%$ & $65.9 \%$ & $\begin{array}{l}100 . \\
0 \%\end{array}$ \\
\hline \multirow{6}{*}{$\begin{array}{l}\text { High } \\
\text { Income }\end{array}$} & \multirow{4}{*}{$\begin{array}{l}\text { Is information } \\
\text { on SWHs } \\
\text { available for } \\
\text { the public? }\end{array}$} & \multirow[b]{2}{*}{ Yes } & Count & 8 & 13 & 21 \\
\hline & & & $\begin{array}{l}\% \text { of } \\
\text { Total }\end{array}$ & $5.9 \%$ & $9.6 \%$ & $\begin{array}{c}15.4 \\
\% \\
\end{array}$ \\
\hline & & \multirow[b]{2}{*}{ No } & Count & 24 & 91 & 115 \\
\hline & & & $\begin{array}{l}\% \text { of } \\
\text { Total }\end{array}$ & $17.6 \%$ & $66.9 \%$ & $\begin{array}{c}84.6 \\
\% \\
\end{array}$ \\
\hline & \multirow{2}{*}{\multicolumn{2}{|c|}{ Total }} & Count & 32 & 104 & 136 \\
\hline & & & $\begin{array}{l}\% \text { of } \\
\text { Total }\end{array}$ & $23.5 \%$ & $76.5 \%$ & $\begin{array}{l}100 . \\
0 \%\end{array}$ \\
\hline
\end{tabular}

Source: Author-generated field data

Figure 19 below indicates that the majority of the respondents (89\%), thought the government was not doing enough to encourage people to use SWHs. Their reasons for holding this view were that there were no strategies in place to teach people on the possibilities of using solar energy as an environmentally friendly natural resource, and that coal- generated electricity was the only source of energy that was mostly promoted despite its harmful environmental effects. Only $11 \%$ agreed that here and there they could hear something about solar energy, but there was never follow-up and action.

Do you think the government is doing enough to promote SWHs?

$\square$ Yes $\quad$ No

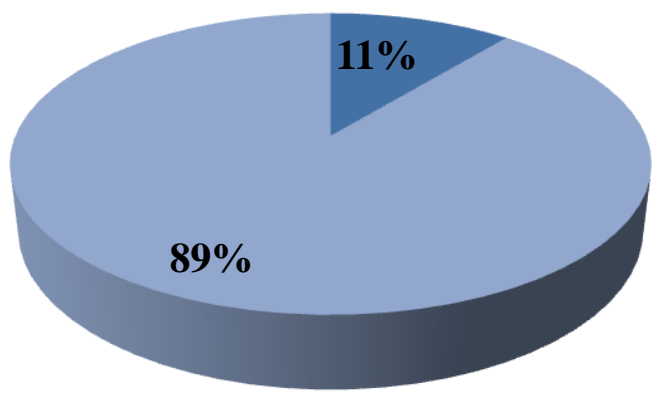

Figure 19 Government's efforts to promote SWHs

Source: Author-generated field data

\subsubsection{Highlights of findings for Objective 3: To analyze determinants of household attitudes towards SWHs}

Below were the key findings under the final objective of the study:

i. Staying in low income or high income residential area seemed to have an influence on willingness to adopt SWHs

ii. The majority of males would consider using SWHs.

iii. The more educated the respondent was the more likely they were to adopt the use of SWHs.

iv. Knowledge about solar energy seemed to influence its adoption in both income groups.

\subsection{Discussion of Results}

This section discusses the study's results, as much as possible in relation to the findings of similar studies done elsewhere. The discussion is patterned against the three objectives. Accordingly, the first sub-section discusses household perceptions and attitudes towards SWHs; the second subsection focuses on results on official attitudes towards SWHs; and the last sub-section discusses the issue of possible determinants of household attitudes towards SWHs.

\subsubsection{Household perceptions and attitudes towards SWHs}

The results of the study indicate that there was a high level of awareness of solar energy as a clean energy source and its use for water heating among residents of Gaborone; but, as indicated by Appendix 2, this awareness is more significant (widespread) among high income households. However, it 
was also evident from the data that the technicality of how solar energy could save costs was not clearly understood by the public, meaning that people's use or potential use of SWHs was not presently influenced by monetary incentives or considerations. This was worsened by the fact that information on SWHs was not easily available to the public (Figure 17). Such access to information on SWHs and the tangible benefits of their adoption was critical because research has established that for people to choose whether to reject or accept a new technology, they had to be fully aware of its advantages over another and be fully convinced that the product could meet their needs (Sæle \& Cherry 2017). The findings of the study also established that awareness of SWHs was positively influenced by education; among the respondents of both income levels awareness increased with the level of education attained. It was also encouraging that respondents from both income groups were keenly aware of the negative and positive environmental implications of using coal and solar power, respectively (Table 5). This bodes well for promoting adoption of SWHs because, as Kariuki (2018) reported, lack of environmental awareness and failure to relate local environmental issues with the global issues (such as climate change) made it difficult for people to understand how their energy choices were harmful to the environment.

In terms of attitudes, the study had revealed that the majority of the Gaborone public was willing to adopt SWHs on condition that they were reliable, user friendly, cost effective and long lasting. This finding was in line with Rogers' diffusion of innovation theory, which asserted that the adoption of a new technology such as SWHs was influenced by three aspects; the innovation should be user friendly, it should address the needs of consumers and it should have a good reputation (Dearing \& Cox 2018). Unfortunately, these conditions did not yet prevail in Gaborone because the study also established that there were presently very few households using solar energy to heat water. As discussed later, this situation was due to a number of barriers which had rendered SWHs a less viable alternative to conventional and less environment friendly energy sources, much in line with the findings of Sæle \& Cherry (2017). Further, the public's positive attitude towards SWHs was not associated with the high environmental concern reported in Figure 15. This situation, as argued by Goldschmidt et. al. (2019), needed to change by demonstrating the link between solar energy and environmental and human health. According to the present study, the Government had a critical role in demonstrating this.

The Gaborone public expected the Government to promote the adoption and use of SWHs by highlighting its environmental and other benefits and by being exemplary in adopting and using SWHs in government establishments (e.g schools, health institutions and government houses). In line with the findings of the international literature reviewed by International Trade Administration (2021), the present study established that the Government of Botswana was perceived not to be doing or have done enough to encourage people to use SWHs, as was evidenced by the absence of efficient public education on SWHs and continued investment into coal-based energy generation projects.

\subsubsection{Official attitudes towards SWHs}

The study found out that officials had a positive attitude towards green sources of energy and this attitude had a strong effect on the willingness to promote the use of solar energy looking at the growing demand for energy and the consequences of burning more coal to meet this demand. This finding was in line with the finding of Adams (2011),that every country had various reasons to promote and implement energy policies for the adoption of SWHs depending on their local need.

This research found that there were positive official initiatives in place to promote the use of solar energy, though these were challenged by lack of funds but there were strategies again to source funds for these initiatives. These initiatives should be encouraged and sustained because, as Kannan \& Vakeesan (2016) have found out, national attempts to promote solar power could reduce carbon emissions at a national level and also create added benefits such as employment opportunities and contribute to the nation's economic development.

A major challenge in government's efforts to lead by example was the inadequacy of the pool of institutional houses for civil servants. This meant that most civil servants lived in rented houses where, as tenants, they did not have a choice but to use the electric geysers they found. This was in line with the finding of Karakaya \& Sriwannawit (2015) that people who first built their houses seemed to have set a trend for the current ones, as shown by constructors who were still maintaining the old building system instead of coming up with new building technologies that support the installation of solar panels.

Despite their efforts and strategies to promote SWHs, vendors conceded the problem of relative unaffordability. Indeed, the relatively high cost of solar energy technology had been reported as a barrier to adoption even in developed countries such as the UK Kariuki (2018). Thus, without government subsidy interventions, SWH adoption among low-income households was unlikely to materialize due to the high cost of procurement, installation and maintenance.

\subsubsection{Determinants of household attitudes towards SWHs}

This study had revealed the critical role of awareness, access to information and knowledge about SWHs in the adoption and use of this renewable energy technology. It had been established that the very low adoption and use of SWHs among Gaborone residents was due to a combination of a) limited knowledge on the relative environmental and financial benefits of SWHs; b) limited knowledge of SWH vendors in the city; c) ignorance among high income house owners about the relative ease with which conventional geysers could be adapted to concurrently serve as SWH tanks as well; d) misperceptions among low income residents living in small 
housing units that SWHs were designed or meant only for the bigger houses of the wealthy; and e) the high cost of SWH adoption (already noted above). Thus, although the study also revealed high willingness to adopt and use SWHs across Gaborone's income categories, there was need for concerted efforts to raise awareness and knowledge about SWHs, their tangible benefits, and about reliable information sources (i.e. about reliable SWH vendors) in the city. Indeed other studies and reports had identified lack of knowledge, communication and access to information about available energy options as a key barrier to the adoption of renewable energy technologies in general and SWHs in particular.

\section{CONCLUSIONS AND RECOMMENDATIONS}

\section{a. Introduction}

This chapter presents conclusions drawn from the study, provides policy recommendations, and makes recommendations for further study regarding household and official attitudes towards the use of domestic solar energy, specifically Solar Water Heaters (SWHs).

\section{b. Conclusions}

The study sought to compare household and official attitudes towards the use of domestic solar energy and to find out the determinants of household attitudes towards the adoption of solar energy. For ease of reference and convenience of the reader, the study's objectives and research questions have been reproduced in Box 1 below. The conclusions are then presented against each respective objective:

RESEARCH OBJECTIVES \& QUESTIONS
Objective 1: To establish household perceptions and attitudes towards SWHs
$>$ To what extent are the residents of Gaborone aware of SWHs?
$>$ What feelings do residents of Gaborone hold towards SWHs?
$>$ What do householders like or dislike about the water heating systems they are currently using and
Objective 2: To find out official attitudes towards SWHs
$>$ What are the official actions/initiatives towards promotion of the use of domestic SWHs?
$>$ How do officials justify the promotion of the use of domestic SWHs?
Objective 3 : To analyze determinants of household attitudes towards SWHs
$>$ What factors have influenced Gaborone residents to choose their current water heating systems?

Objective 1: To establish household perceptions and attitudes towards SWHS

Regarding household awareness about SWHs, the study concludes that respondents were aware of solar energy and that it could be used for water heating purposes. This awareness was particularly evident among high income households. Households in both high and low income residential areas were aware that solar energy is a clean form of energy and that burning coal to produce energy is harmful to the environment. However, few of the households were using solar energy in their homes. Education tended to increase awareness of and concern for environmental issues; nearly all respondents who had attained a higher education level were aware of positive properties and benefits of solar energy and hence their concern about environmental changes taking place around them as they witnessed their consequences or heard about them. Awareness of drought was predominant among the respondents in all income levels as they heard about it more often than other environmental terms such as renewable energy and climate change. The study concludes that there is limited information on SWHs in Gaborone, even when one heard a bit about it there was no place one could visit to enquire more about SWHs. Residents heard more about conventional energy instead, how to save it and where it was sold. Lack of information about the benefits of solar energy, the installation possibilities of SWHs, its 
reliability, durability and costs has had an impact on the adoption of SWHs.

Overall attitudes of both high and low income households in this study showed that Gaborone residents were generally receptive to the use of domestic solar energy. However, the results of this study supported the need for awareness building and capacity building from both the government officials and distributors of SWHs. When people are used to a product; they might resist adoption of a new product unless they were fully aware of its relevance regarding their daily activities. Positive attitude towards the use of SWHs was not linked to environmental concern, although solar energy was viewed as clean. This study has revealed a pervasive view that it was the responsibility of the government to promote SWHs since the government was the main energy service provider and a major decision maker when it came to such issues as adoption and capacity building.

\section{Objective 2: To find out official attitudes towards SWHS}

Government had initiatives in place to promote the use of solar energy through policy development, promotions and campaigns. Solar energy was taught to students in schools through environmental clubs and contribution of government was to provide learning guides through the relevant departments such as the Department of Environmental Affairs (DEA). Public demonstrations of SWHs were also held and interested individuals were referred to the distributors for other details. However, it was evident from key informant interviews that there was no official follow up on these efforts and therefore the same routine was being followed without tracking its efficiency and making advanced improvements.

All in all, the government seemed not to be fully committed to promoting solar energy since there were no payment plans or any financial assistance for the low income households despite the high costs associated with installing SWHs. There were no evident collaborations between the officials (government) and vendors concerning the promotion of SWHs and funding scheme plans since it is concluded that SWHs were pricey for low income earners who were consequently forced to use energy sources they could afford despite their actual and potential harm to environmental and human health.

With regard to the adoption of SWHs among government officials, the study had established that, on the whole, officials had not adopted SWHs in large numbers because institutional (government) houses were very few and did not accommodate all of them. They lived in rented houses close to their duty stations and almost all of those houses used electric geysers to heat water. They did not have an upper hand in changing those to solar energy. In the cases where the officials had bought their houses, they found electric geysers already installed and they were not fully aware they could replace those with SWHs or adapt them to serve as solar water heaters as well. Therefore, they just used them for their own convenience as long as they could afford their electric bills. Environmental concern became a theoretical aspect in this case. Further, the drive to promote SWHs in institutional houses and buildings had not been backed by sufficient funding. For example, an ongoing project of assessing SWHs in government institutions to establish how many SWHs needed maintenance and replacement, how many were not working, what faults were there and cost implications came to a halt due to insufficient funds.

\section{Objective 3: To analyze determinants of household attitudes towards SWHs}

The study has shown that the level of knowledge/awareness about renewable energy products in Gaborone was very low, especially in low income residential areas and this was positively associated with low level of adoption. Consumers were ill-informed about how effective, reliable, durable SWHs were. There was rather a relatively high awareness about conventional energy sources and hence their massive adoption. There was an apparent sense of low esteem among low income earners as they thought SWHs were meant for the rich and their bigger houses; this obviously affected their interest in knowing more about the product and ultimately deciding to use it.

Poor marketing strategies by distributors had also contributed to the low adoption rates for SWHs. Information on SWHs was not as widespread and as a result many potential consumers were not aware that it was a worthwhile investment. They would have many questions about the product but were not sure about where to go for clarity; for example they would want to know how SWHs provide hot water during winter, night time or when its cloudy: wouldthey have some kind of a back-up or not? Therefore, the public, especially those in low income levels and those who did not achieve high education level were not so convinced about the benefits of domestic solar water heaters.

One of the key determinants of household attitudes towards SWHs was lack of government policies and strategies that supported the use of domestic solar energy. The findings suggest that the Gaborone community held the government officials responsible for the limited adoption of SWHs as they noticed that more policies and attempts in the energy sector supported conventional energy development. This did not allow consumers to understand the negative impacts of conventional energy as compared to solar energy. There were no compulsory standards regarding the adoption of SWHs and therefore the public was not under any pressure to consider solar energy.

The study has also revealed limited official or institutional demonstration effect in terms of SWH adoption due to shortage of institutional houses and hence low official uptake. Furthermore, a lot of Gaborone residents live in rented houses which meant they did not have control over the type of heating system to use. It was relatively expensive to install SWHs and hence the reason for not considering it whenever building a house, and there were no government subsidy schemes to assist with SWH adoption. 


\section{c. Recommendations}

The following are recommendations offered based on the findings of the study. These suggestions are made for the population of the study, that is; the officials, the distributors of SWHs and the Gaborone public at large and also specifically for policy and further research, as indicated below:

i. For the target population:

i) Officials

- Public servants should once in a while attend workshops and trainings on SWHs regarding their environmental and economic benefits so that even when they build their own houses they can consider installing them based on their knowledge and first hand experiences.

- The officials should come up with a tool to assess the effect of campaigns on domestic solar energy; in that way they will be in a position to track progress in the adoption of SHWs and it will also help in future planning.

- There should be relaxed financing schemes to assist those who are interested in installing SWHs in their houses to make them affordable to a lot of individuals. The officials should increase the limitation of electricity during peak hours and pick supply so that people cannot use their geysers. They can then consider other available alternatives such as domestic solar energy.

- The government should promote the usefulness of domestic solar energy more than promoting unclean energy sources to encourage public acceptance of SWHs. The study suggests promoting community campaigns through mass media.

\section{ii) Distributors of $\mathrm{SWHS}$}

- Information on SWHs should be given to the residents individually, that is through door-to-door visits, to ensure maximum coverage. As service providers, distributors of SWHs need to outwork themselves to educate communities about the benefits of renewable energy technologies such as solar water heaters so that they can be of value to them and to increase their market as well.

- The study also suggests distributors employing publicity officers whose main responsibility would be to take advantage of public gatherings and inform them about the SWHs and perhaps note their suggestions for further discussion with the relevant authorities.

- It is also suggested that the distributors of SWHs liaise with government officials, especially in the Department of Energy Affairs, about possible funding possibilities and develop a joint policy on how best they can disseminate information to the public on domestic solar energy. Where there are competitions and winners are given SWHs, the study recommends close monitoring of the devise and feedback from the users. This can also help advertise the system and ensure it serves its purpose to the end user.

\section{iii) The Public}

- Batswana should act now against the effects of burning excessive coal to generate more electricity because in future they might end up being prohibited from using Morupule B to generate more electricity by the World Bank and other UN bodies considering its potential harm to the environment. It will then be painful to adapt than now when they still have a choice.

- The study suggests that those who have firsthand experience with domestic solar energy and are well informed about how it operates should help spread the word and make a difference because pointing fingers at the government for not doing enough to promote SWHs would not solve the issues of global warming.

- The public should attend public gatherings because that is where most information is shared about emerging issues, they should also act responsibly and understand that their maximum cooperation makes it easy for the implementation of different policies, they should also seek to learn and ask questions about products introduced to them.

- Households should weigh short-term procurement and installation costs against lasting or long-term savings on domestic energy.

ii. Policy recommendations

- The study has highlighted the need to revisit the current public and private education policies in Botswana in order to introduce and enhance policies aimed at cultivating a deeper understanding of solar energy, its uses, benefits and effectiveness. Successful implementation can be achieved through developing the knowledge capacities of teachers on solar energy at primary, junior secondary, senior secondary and tertiary levels. This can apply to both government and private schools.

- Environmental Education should be incorporated in the school curriculum for awareness at a tender age. The government should emphasize the availability of active environmental clubs in schools and make once in a while visits to track their progress in raising environmental awareness. Nationally recognized competitions should also be considered to encourage schools to take part in emerging environmental issues and to also instill a sense of responsibility for whatever possible consequences. 
- The government should diversify energy sources by also having a local supplier of renewable energy, in this case solar energy. This can first be achieved by creating an enabling environment for all government sectors/departments to use solar energy and be exemplary to the public. By so doing, the officials can play a key role in eliminating uncertainties among the public and their future energy choices.

- The government could subsidize the solar energy sub-sector so that SWHs can be sold at a reasonable price to the poor citizens just like what the Agriculture Department did with stock feeds and other selected agricultural products and services to attract citizens into agricultural activities.

- The company that is awarded a tender of installing SWHs and or replacing electric geysers with SWHs should be given a mandate of informing the house occupants about their products and also be given another package of regular monitoring and maintenance since they are the ones who are fully knowledgeable about their products. This will also help them better advertise their products and therefore raise awareness on the use of SWHs.

\section{iii. Recommendations for further research}

- Further studies could assess the current education system on solar energy, its limitations and make strategies that could be put in place to ensure its effectiveness especially from an early education age.

- To be fully functional, Morupule B requires regular maintenance, skilled workforce and a highly recommendable project manager. A study is suggested to compare the costs of maintaining Morupule B to its expected standards, with those of establishing and maintaining a solar energy-based power plant and providing SWHs (active and/or passive).

- Related to the preceding recommendation, there is need for a comparative cost-benefit analysis of SWHs vs conventional electric geysers taking into account both tangible and intangible, as well as direct and indirect costs and benefits, using the same time horizon and discount rate. The results could be instructive in promoting SWHs among the public.

\section{ACKNOWLEDGEMENTS}

First and foremost, I would like to thank the Almighty God for making it possible for me to complete this study; I would not have done it without him by my side.

I wish to acknowledge the following people for their maximum support and contributions to the outcomes of this dissertation with the deepest gratitude,

- Prof. Raban Chanda, my supervisor for generously sharing his wisdom, for his guidance, patience, encouragement and all that I have learnt from him throughout this entire study.
- The Ministry of Environment, Wildlife and Tourism for granting me permission to conduct the study.

- Dr S.R.T Moeng, for tutorials on the statistical analysis of this study.

- Mosimanegape Nondo, my loving husband for basic SPSS tutorials and endless support.

- Mercy Meykie Marumo, my lovely sister for helping me administer questionnaires.

- The communities of the Village and Old Naledi for their contribution and cooperation during the data collection of this study.

- The Department of Energy Affairs, Department of Environmental Affairs, Sola Hart and Solar Power for allowing me to conduct interviews with their employees.

\section{REFERENCES}

[1] Adams S 2011: South African consumer attitudes towards domestic solar power systems. MSc Thesis. University of Pretoria. Gordon Institute of Business Science.

[2] Africa Hub 2021: Sustainable Energy for all. SEforALL Africa Hub. viewed 03 October 2021, <https://www.se4allafrica.org/seforall-in-africa/country-data/botswana/>

[3] Ajaps S \& McLellan R| Kris Gritter (Reviewing Editor 2015: "We don't know enough", Environmental education and proenvironmental behaviour perceptions, Cogent Education, 2:1, DOI, 2021, 10.1080/2331186X.2015.1124490

[4] Ajzen I 1991: The theory of planned behaviour. Organizational Behaviour and HumanDecision Processes,50, 179-211.

[5] Belyakov N 2019: Sustainable Power Generation Current Status, Future Challenges and Perspectives, Sustainable Power Generation, viewed 04 October 2021, <https://www.sciencedirect.com/book/9780128170120/sustainable -power-generation>

[6] Bhandari $\mathrm{P}_{-}$2020._ An introduction to qualitative research. Methods and Examples-Scrbbr. viewed 05 October 2021.< https://www.scribbr.com/methodology/qualitative-research/>

[7] Bhandari P 2020: An introduction to quantitative research, Methods and Examples-Scrbbr. viewed 05 October 2021, <https://www.scribbr.com/methodology/quantitative-research/>

[8] Boden T A, Marland G \& Andres R J 2017: National CO2 Emissions from Fossil-Fuel Burning, Cement Manufacture, and Gas Flaring: 1751-2014, Carbon Dioxide Information Analysis Center, Oak Ridge National Laboratory, U.S. Department of Energy, doi 10.3334/CDIAC/00001_V2017.

[9] Botswana Power Report Q3 2012: Business Monitor International, viewed $11 \quad$ January 2015, <http://www.en.m.wikipedia.org/wiki/Energy_in_Botswana>

[10] Bulsara C 2011: Using a mixed methods approach to enhance and validate your research, viewed 11 January 2015, http://www.nd.edu.au/downloads/research/hrr/using_mixed_meth ods_approach_to-enhance_and_validate_your_research.pdf

[11] Carbon and Brief 2020: Mapped : The world's coal power plants. Carbon Brief Ltd 2021.

[12] Central Statistics Office 2011: Botswana Population and Housing Census, viewed 13 August 2015, <http://www.citypopulation.de/Botswana.htm>

[13] Chanda R (1992): Correlates and dimensions of environmental quality concern among residents of an African Subtropical City: Gaborone, Botswana Journal of Environmental Education, 30(2), 31-39.

[14] Chevron Corporation 2014: Energy Supply \& Demand, viewed 22 April 2015, <http://www.chevron.com/globalissues/energy/supply demand> 
[15] Dearing J \& Cox J 2018 : Diffusion Of Innovations Theory, Principles, And Practice . Health Affairs. Vol. 37, No. 2: Diffusion Of Innovation, viewed 05 October 2021. <https://www.healthaffairs.org/doi/10.1377/hlthaff.2017.1104>

[16] Department of Energy \& Climate Change 2012: Public Attitudes Tracker -Wave 1: Summary of Key Issues. London, Department of Energy and Climate Change.

[17] Drysdale N 2021 :How the 4 Principles of Health Care Ethics Improve Patient Care. Clipboard Health. viewed 05 October 2021,https://clipboardhealth.com/how-the-4-principles-of-healthcare-ethics-improve-patient-care

[18] Energy and Environment Partnership 2017: Renewable Energy Market Landscape Study covering 15 countries in Southern and East Africa, viewed 05 October 2021. https://entwicklung.at/fileadmin/user_upload/Dokumente/Regione n/Volume_I_Market_Landscape_Study_EEP-SEA_

[19] Flake J K, Pek J \& Hehman E 2017: Construct Validation in Social and Personality Research: Current Practice and Recommendations. Social Psychological and Personality Science, 8(4), 1-9.

[20] Global Energy Review 2021: Assessing the effects of economic recoveries on global energy demand and Carbon dioxide emissions in 2021. International Energy Agency

[21] Goldschmidt R, Richter A \& Pfeil R 2019: Active stakeholder involvement and organisational tasks as factors for an effective communication and governance strategy in the promotion of etaxis. Results from a field research lab ,Energy Pol, 135. Google $\underline{\text { Scholar }}$

[22] International Energy Agency (IEA) (2019) PVPS Executive Committee Members PV annual report 2019 Google Scholar

[23] International Energy Agency 2021: Global Energy Review, Assessing the effects of economic recoveries on global energy demand and CO2 emissions in 2021, viewed 04 October 2021, < www.iea.org >

[24] International Energy Outlook 2019: Today in Energy, viewed 02 October <http://www.eia.gov./todayinenergy/detail.php?id+41433>

[25] International Trade Administration 2021: Botswana Energy Guide , viewed 02 October 2021, <https://www.trade.gov/countrycommercial-guides/botswana-energy $>$

[26] IRP Report 2020: Integrated Resource Plan for Electricity for Botswana, viewed

03

October2021, <http://www.bera.co.bw/downloads/Electricity/Abri dged\%20IRP\%20Report\%20Botswana\%2016\%20November\%20 2020.p.df.>

[27] Kannan N \& Vakeesan D 2016: Solar energy for future world: A review.Renewable and Sustainable Energy Reviews, 62:10921105 .

[28] Karakaya E \& Sriwannawit P 2015: Barriers to the adoption of photovoltaic systems: The state of the art, Renewable and Sustainable Energy Reviews, 49: 60-66.

[29] Karatayev M \& Clarke M L 2016: A review of current energy systems and green energy potential in Kazakhstan.Renew. Sustain. Energy Rev. 2016,55, 491-504. [CrossRef]

[30] Kariuki D 2018: Barriers to Renewable Energy Technologies Development., Energy Today, viewed 02 October 2021, <https://www.researchgate.net/publication/348936339_Barriers_t o_Renewable_Energy_Technologies_Development >

[31] Karlstrøm H \& Ryghaug M 2014: Public attitudes towards renewable energy technologies in Norway. The role of party preferences Energy Pol, 67, pp. 656-663 ArticleDownload PDFView Record in ScopusGoogle Scholar

[32] Kaur P, Stoltzfus J \& Yellapu V 2018: Descriptive Statistics Department of Research and Innovation, The Research Institute, St. Luke's University Health Network; Temple University School of Medicine, Bethlehem, PA 18015, USA

[33] Kuhn G 2020: The Pros and Cons of Open-Ended Questions and Close- Ended Questions Drive Research, viewed 05 October 2021, <http://www.driveresearch.com/market-research-companyblog/the pros-and-cons-of-open-ended-questions-and close-endedquestions/>
[34] Margaret R 2019: A Quality Approach to Qualitative Content Analysis: Similarities and Differences Compared to Other Qualitative Methods [46 paragraphs]. Forum Qualitative Sozialforschung / Forum: Qualitative Social Research, 20 (3), Art. 31, viewed 05 0ctober 2021, <http://dx.doi.org/10.17169/fqs20.3.3385.>

[35] Mateus S 2011: Public and Social Experience, viewed 25 April 2015, 〈http://www.en.m.wilkepedia.org/wiki/public>

[36] McCombes S 2019: An introduction to sampling methods, v iewed $05 \quad$ October 2021. <https://www.scribbr.com/methodology/sampling-methods/>

[37] McLeod S A 2019: Likert scale;Simply Psychology, viewed 05 October 2021, <https://www.simplypsychology.org/likertscale.html>

[38] Ministry of Mineral Resources, Green Technology and Energy Security (MMGE) Draft National Energy Policy Report 2016: Government of the Republic of Botswana

[39] Mokaila K 2013: 'Minister Mokaila briefs parliament on Morupule B', Botswana Daily News (Parliament), viewed 1 March 2014, < http://www.dailynews.gov.bw/newsdetails.php?nid=1346>

[40] Moreri S 2014: Eskom 'threatens to cut power supply to Botswana', Sunday Standard News (Sunday Standard Reporter), March 09-15, p.3.

[41] Nastasi, B n.d: Qualitative Research: Sampling and Sample Size Considerations, viewed 12 May 2014,<http://my.laureate.net/faculty/docs/faculty\%20Documents/q ualit_res_smpl_size_consid_doc >

[42] National survey report of PV power applications in Sweden , International Energy Agency (2018), pp. 1-24 no. August, View Record in ScopusGoogle Scholar

[43] Pitse R 2013: Morupule B Contractor owes taxman P600m, threatens project shutdown, viewed 13 December 2016, < http://www.sundaystandard.info/article.php?NewsID=16489>

[44] Rajamani M 2021: Botswana's Renewable Energy Options- The $\begin{array}{lllll}\text { Borgen Project, viewed } 04 & \text { October } 2021\end{array}$ <https://borgenproject.org/botswanas-renewable-energy/>

[45] Ramokopelwa K 2014: 'Inflation to close year at 5.5\%', Botswana Guardian Newspaper (BG Markets), 06 June, p.2.Report.pdf

[46] Reuters Staff 2020 : Botswana Power, viewed 02 October 2021, $<$ https://www.reuters.com/article/botswana-poweridUSL8N2BI5Z9>

[47] Ritchie H \& Roser M 2020: "Energy".Renewable Energy Generation. OurWorldInData.org. viewed 05 October 2021. https://ourworldindata.org/energy

[48] Sæle H \& Cherry T L 2017: Attitudes and perceptions about becoming a prosumer: results from a survey among Norwegian Residential customers - 2016 SINTEF Rapport; 2017: 00078 Google Scholar

[49] Saleh AM, HarisA\& Ahmed N 2014: Towards a UTAUT-Based Model for the Intention to use Solar Water Heaters by Libyan Households. International Journal of Energy Economics \& Policy, 4, 26-31.

[50] Samantha Gross 2020: Why are fossil fuels so hard to quit? viewed 03 October 2021 <ww. Brookings.edu.>

[51] Seanama Conservation Consultancy 2012: Reflecting on the challenges of attaining a green economy for Botswana. Energy Policy Brief. Gaborone: Government Printers.

[52] Statistics Botswana 2016: Consumer Price Index, Statistics Botswana, viewed 03 October 2021, 〈http://www.cso.gov.bw.>

[53] Statistics Brief, first quarter 2021, Electricity Generation and Distribution. Statistics Botswana.

[54] World Coal Association 2014: Coal Statistics, viewed 16 August 2015, <http://www.worldcoal.org.about.wca>

[55] World Energy Council 2014: Energy Resources, viewed 24 May 2015, <http://www.worldenergy.org.data.resources>

[56] World Energy Outlook 2019: Electricity - World Energy OutlookAnalysis-IEA, viewed 04 October 2021, <https://www.iea.org/reports/world-energy-outlook2019/electricity> 
[57] Wyllie J O Y, Essah E \& Ofetotse E 2018: Barriers of solar energy uptake and the potential for mitigation solutions in Barbados. Renewable and Sustainable Energy Reviews, 91.pp.
935949. ISSN 13640321 doi: viewed 03 october 2021. <https://doi.org/10.1016/j.rser.2018.04.100>

[58] Yamane T 1973: Statistics; An Introductory Analysis. (3 ${ }^{\text {rd }}$ Ed.) New York: Harper \& Row.

\begin{tabular}{|c|c|c|c|c|c|c|c|c|c|c|}
\hline \multicolumn{11}{|c|}{ Appendix 1 Distribution of demographical characteristics according to income levels } \\
\hline & & \multicolumn{6}{|c|}{ Income Level of respondent } & \multirow[b]{3}{*}{$\mathrm{p}$-value } & \multirow[b]{3}{*}{ Chi-square } & \multirow[b]{3}{*}{$\mathrm{df}$} \\
\hline & & \multicolumn{2}{|c|}{ Low Income } & \multicolumn{2}{|c|}{ High Income } & \multicolumn{2}{|c|}{ Total } & & & \\
\hline & & $\mathrm{N}$ & $\%$ & $\mathrm{~N}$ & $\%$ & $\mathrm{~N}$ & $\%$ & & & \\
\hline \multirow{4}{*}{ Broad age group } & $<24$ & 29 & 11.0 & 0 & .0 & 29 & 7.2 & $<0.001$ & 25.174 & 3 \\
\hline & $25-29$ & 46 & 17.4 & 11 & 8.1 & 57 & 14.2 & & & \\
\hline & $30-34$ & 65 & 24.6 & 44 & 32.4 & 109 & 27.2 & & & \\
\hline & $35+$ & 124 & 47.0 & 81 & 59.6 & 205 & 51.2 & & & \\
\hline \multirow{2}{*}{ Gender of respondent } & Male & 109 & 41.3 & 58 & 42.6 & 167 & 41.8 & 0.794 & 0.068 & 1 \\
\hline & Female & 155 & 58.7 & 78 & 57.4 & 233 & 58.2 & & & \\
\hline \multirow{4}{*}{ Type of Employment } & Formal & 59 & 22.3 & 87 & 64.0 & 146 & 36.5 & $<0.001$ & 72.126 & 3 \\
\hline & Informal & 77 & 29.2 & 10 & 7.4 & 87 & 21.8 & & & \\
\hline & Unemployed & 65 & 24.6 & 15 & 11.0 & 80 & 20.0 & & & \\
\hline & Self Employed & 63 & 23.9 & 24 & 17.6 & 87 & 21.8 & & & \\
\hline \multirow{4}{*}{ Education Status } & PSLE & 76 & 28.8 & 5 & 3.7 & 81 & 20.2 & $<0.001$ & 184.277 & 3 \\
\hline & BGSE & 127 & 48.1 & 11 & 8.1 & 138 & 34.5 & & & \\
\hline & COSC & 16 & 6.1 & 1 & .7 & 17 & 4.2 & & & \\
\hline & Tertiary & 45 & 17.0 & 119 & 87.5 & 164 & 41.0 & & & \\
\hline \multirow{5}{*}{ Marital Status } & Single & 221 & 83.7 & 79 & 58.1 & 300 & 75.0 & $<0.001$ & 31.912 & 4 \\
\hline & Married & 38 & 14.4 & 49 & 36.0 & 87 & 21.8 & & & \\
\hline & Divorced & 3 & 1.1 & 6 & 4.4 & 9 & 2.2 & & & \\
\hline & Widowed & 1 & .4 & 1 & .7 & 2 & .5 & & & \\
\hline & Separated & 1 & .4 & 1 & .7 & 2 & .5 & & & \\
\hline \multirow{5}{*}{ Monthly Income } & $>2000$ & & 49.2 & & 3.7 & & 33.8 & $<0.001$ & 227.520 & 4 \\
\hline & $3000-5000$ & & 12.1 & & 8.1 & & 10.8 & & & \\
\hline & 5000-10000 & & 1.5 & & 26.5 & & 10.0 & & & \\
\hline & $<10000$ & & .4 & & 41.9 & & 14.5 & & & \\
\hline & No Salary & & 36.7 & & 19.9 & & 31.0 & & & \\
\hline
\end{tabular}


Appendix 2 Knowledge and awareness by income level

\begin{tabular}{|c|c|c|c|c|c|c|c|}
\hline & & \multicolumn{4}{|c|}{ Income Level of respondent } & \multirow[b]{3}{*}{$\begin{array}{c}\text { Chi-Square } \\
\text { (df) }\end{array}$} & \multirow[b]{3}{*}{ p-value } \\
\hline & & \multicolumn{2}{|c|}{ Low Income } & \multicolumn{2}{|c|}{ High Income } & & \\
\hline & & $\mathrm{N}$ & $\%$ & $\mathrm{~N}$ & $\%$ & & \\
\hline \multirow{5}{*}{ What can it be used for? } & Water heating & 108 & 40.9 & 112 & 82.4 & $66.06(4)$ & $<0.001$ \\
\hline & lighting & 40 & 15.2 & 12 & 8.8 & & \\
\hline & Cooking & 3 & 1.1 & 0 & 0.0 & & \\
\hline & Electric appliances & 75 & 28.4 & 10 & 7.4 & & \\
\hline & Don’t Know & 38 & 14.4 & 2 & 1.5 & & \\
\hline \multirow{2}{*}{ know anything about solar energy } & Yes & 217 & 82.2 & 126 & 92.6 & $8.16(1)$ & 0.017 \\
\hline & No & 46 & 17.4 & 10 & 7.4 & & \\
\hline \multirow{6}{*}{ Environmental Awareness } & Drought & 196 & 74.2 & 96 & 70.6 & $16.43(4)$ & 0.002 \\
\hline & Climate Change & 34 & 12.9 & 30 & 22.1 & & \\
\hline & Renewable energy & 2 & .8 & 4 & 2.9 & & \\
\hline & Solar power & 16 & 6.1 & 6 & 4.4 & & \\
\hline & None of Above & 16 & 6.1 & 0 & .0 & & \\
\hline & Total & 264 & 100.0 & 136 & 100.0 & & \\
\hline \multirow{8}{*}{ Where did you learn terms? } & Educational Institutions & 70 & 26.5 & 57 & 41.9 & $66.77(7)$ & $<0.001$ \\
\hline & Books and pamphlets & 9 & 3.4 & 9 & 6.6 & & \\
\hline & $\mathrm{TV}$ & 30 & 11.4 & 40 & 29.4 & & \\
\hline & Newspaper & 13 & 4.9 & 4 & 2.9 & & \\
\hline & Radio & 73 & 27.7 & 10 & 7.4 & & \\
\hline & Internet & 2 & .8 & 5 & 3.7 & & \\
\hline & Word of Mouth & 38 & 14.4 & 10 & 7.4 & & \\
\hline & Other & 29 & 11.0 & 1 & .7 & & \\
\hline
\end{tabular}

